\title{
POLA AKTIVITAS HARIAN DAN DINAMIKA POPULASI LALAT BUAH BACTROCERA DORSALIS COMPLEX PADA PERTANAMAN JERUK DI DATARAN TINGGI KABUPATEN KARO PROVINSI SUMATERA UTARA
}

\author{
Binari Manurung, Puji Prastowo \& Emmi Ebrina Tarigan \\ Jurusan Biologi-Universitas Negeri Medan, Jln. Williem Iskandar Psr. V Medan Estate. \\ E-mail: binari44@hotmail.com
}

\begin{abstract}
Daily activity pattern and population dynamic of fruit fly Bactrocera dorsalis complex on citrus plantation at highland Karo district North Sumatera Province. The fruit fly Bactrocera dorsalis complex is important pest on citrus plantation at highland Karo district North Sumatera Province. The studies with the aim to find out its daily activity pattern and population dynamic on citrus plantation have been done. Fruit flies were collected by water bottle trap with methyl eugenol attractant. Sampling for daily activity pattern was done per two hours for two months (April to May 2011) from 06.00 a.m until 18.00 p.m. Meanwhile, population dynamic study was conducted on two citrus plantations per four days for nine months (March to November 2011) in the first and third week of each month. The research result showed that B.dorsalis complex was more active during morning at 10.00 to $12.00 \mathrm{a}$.m. The peak abundance of fruit fly occurred at the end of June until beginning of July. The peak population coincided with the ripening period of fruits, low number of rainy $(\mathrm{d})$ and rainfall $(\mathrm{mm})$ in June and July periods. There was a significant correlation between number of rainy day and rainfall with fruit flies caught per month $(\mathrm{R}=0.79 ; \mathrm{Y}=$ $\left.289.34+14.23 \mathrm{X}_{1}-15.93 \mathrm{X}_{2} ; \mathrm{R}^{2}=0.62 ; \mathrm{P}<0.05\right)$. The pattern of fruit fly fluctuation in two citrus plantations was similar $\left(\mathrm{r}_{\mathrm{s}}=0.47\right.$; $\mathrm{P}<0.05)$.
\end{abstract}

Keywords: fruit fly Bactrocera dorsalis complex, daily activity pattern, population dynamic

\begin{abstract}
ABSTRAK
Pola aktivitas harian dan dinamika populasi lalat buah Bactrocera dorsalis complex pada pertanaman jeruk di dataran tinggi Kabupaten Karo Provinsi Sumatera Utara. Lalat buah Bactrocera dorsalis complex merupakan hama penting tanaman jeruk di dataran tinggi Kabupaten Karo-Provinsi Sumatera Utara. Suatu penelitian yang bertujuan untuk mengkaji pola waktu aktivitas harian dan dinamika populasinya telah dilakukan. Sampel lalat buah ditangkap dengan menggunakan perangkap Steiner (botol bekas air mineral) yang diberi zat pemikat metil eugenol. Sampling untuk kajian pola aktivitas harian dilakukan per dua jam selama dua bulan ( April -Mei 2011) dari pukul 06.00-18.00 WIB, sedangkan untuk dinamika populasi dilakukan pada dua pertanaman jeruk per empat hari selama sembilan bulan (Maret 2011-November 2011) yakni pada minggu I dan III setiap bulannya. Hasil penelitian menunjukkan B. dorsalis complex lebih aktif pada pagi hari pukul 10.00-12.00 WIB. Kelimpahan puncak terjadi pada akhir Juni hingga awal Juli. Puncak populasi terjadi bersamaan dengan masa pematangan buah jeruk, rendahnya jumlah hari hujan dan curah hujan pada bulan Juni dan Juli. Terdapat hubungan yang signifikan antara jumlah hari hujan dan curah hujan dengan jumlah lalat buah yang tertangkap setiap bulan $\left(\mathrm{R}=0,79 ; \mathrm{Y}=289,34+14,23 \mathrm{X}_{1}\right.$ $\left.15,93 \mathrm{X}_{2} ; \mathrm{R}^{2}=0,62 ; \mathrm{P}<0.05\right)$. Dinamika populasi lalat buah pada dua lokasi pertanaman jeruk yang diselidiki menunjukkan pola yang relatif sama $\left(\mathrm{r}_{\mathrm{s}}=0.47 ; \mathrm{P}<0.05\right)$.
\end{abstract}

Kata kunci: lalat buah Bactrocera dorsalis complex, pola aktivitas harian, dinamika populasi

\section{PENDAHULUAN}

Kabupaten Karo yang berada di daerah pegunungan pada ketinggian $1400 \mathrm{~m}$ di atas permukaan laut merupakan salah satu pusat produksi buah-buahan, khususnya jeruk manis (Citrus sp.). Namun produksi jeruk dari Kabupaten tersebut sejak tahun 2003 telah mengalami penurunan yang sangat drastis. Hal itu terjadi karena buah tanaman jeruk yang berada di daerah ini diserang oleh lalat buah Bactrocera sp. (Diptera: Tephritidae). Menurut Hasyim et al. (2008) sebagai salah satu serangga hama penting tanaman hortikultura di daerah tropis dan subtropis, lalat buah meletakkan telurnya di bawah kulit buah, kemudian menetas menjadi larva dan selanjutnya mengkonsumsi daging buah. Buah yang terserang lalat buah akan menjadi lebih cepat busuk dan jatuh dari pohonnya sebelum waktunya (Hutasoit, 2004). 
Hama lalat buah diperkirakan telah merusak sekitar 17.000 hektar tanaman jeruk yang berada di daerah Kabupaten Karo dan menyebabkan produksi per hektarnya mengalami penurunan yang drastis menjadi 20 ton dari sebelumnya 60 ton. Bahkan kualitas buah jeruk yang dihasilkannya juga amat buruk sehingga harga jualnya di tingkat petani turun hingga 50\% (Manik \& Bangun, 2004).

Surat Kabar Harian Medan Bisnis pada 31 Mei 2004 memberitakan bahwa lalat buah yang menyerang tanaman jeruk yang berada di dataran tinggi provinsi Sumatra secara signifikan mampu mengurangi produksi sampai $70 \%$. Sehubungan dengan masalah tersebut pada bulan Mei 2004 gerakan pengendalian massal lalat buah telah dicanangkan, ditandai dengan pemukulan gong oleh Menteri Pertanian Republik Indonesia.

Salah satu langkah penting yang harus dilakukan dalam rangka monitoring dan pengendalian lalat buah yang menyerang tanaman jeruk adalah memahami bioekologi dari lalat buah tersebut. Sejumlah hasil penelitian tentang bioekologi lalat buah Bactrocera spp. telah dilaporkan oleh beberapa peneliti. Misalnya, Shehata et al. (2008) tentang biologi perkembangannya; Hasyim et al. (2008) tentang fluktuasi populasinya, Chen et al. (2006) perihal migrasi dan perubahan populasinya; dan Asokan et al. (2007) tentang biologi molekularnya.

Informasi mengenai bioekologi lalat buah Bactrocera spp. yang menyerang tanaman jeruk di Kabupaten Karo Sumatera Utara masih sangat terbatas. Penelitian yang telah dilakukan diantaranya masih berkaitan dengan keanekaragaman spesies dan pengaruh metil eugenol dalam pengendalian populasinya. Spesies lalat buah yang menyerang tanaman jeruk adalah Bactrocera dorsalis dan metil eugenol dengan menggunakan perangkap Steiner dapat dipergunakan untuk mengendalikan populasinya (Tobing et al., 2007).

Penelitian bertujuan untuk mengetahui pola aktivitas harian, kelimpahan dan dinamika populasi lalat buah dalam hubungannya dengan tingkat kematangan buah jeruk, perbedaan kelimpahan dan pola dinamika populasi lalat buah pada dua pertanaman jeruk serta hubungan antara faktor lingkungan (iklim) dengan kelimpahan/dinamika populasi lalat buah. Pemahaman tentang hal ini mempunyai kontribusi penting dalam monitoring ataupun pengendalian populasi lalat buah di lapangan. Kepentingan data semacam itu untuk monitoring dan pengendalian populasi serangga di lapangan saat menjadi hama pertanian telah dilaporkan oleh Manurung et al. (2004 \& 2005).

\section{METODE PENELITIAN}

Pola Aktivitas Harian. Penelitian dilakukan pada pertanaman jeruk manis di Desa Semangat Kecamatan Merdeka yang terletak pada ketinggian sekitar $1360 \mathrm{~m}$ di atas permukaan laut. Luas pertanaman jeruk tersebut $3000 \mathrm{~m}^{2}$ dan terdapat 500 pohon jeruk. Tanaman jeruk telah berumur sekitar 7 (tujuh) tahun. Pemerangkapan lalat buah dilakukan dengan menggunakan tipe perangkap Steiner yang telah dimodifikasi, yakni berupa botol bekas air mineral berukuran $1500 \mathrm{ml}$ yang salah satu bagian ujungnya diubah sedemikian rupa sehingga dapat berperan sebagai pintu masuk bagi lalat buah (Putra, 1997; Gupta \& Bhatia, 2000; Kardinan, 2003 \& Hasyim et al., 2008). Pada kawat yang terdapat pada bagian dalam botol digantungkan kapas sebesar ibu jari dan ditetesi zat pemikat metil eugenol sebanyak empat tetes. Perangkap digantung pada pohon jeruk pada ketinggian 1,5 meter dari permukaan tanah. Jumlah perangkap yang digunakan sebanyak 20 buah. Pemasangan perangkap berlangsung dari pukul 06.00 hingga pukul 18.00 WIB. Pemerangkapan dilakukan satu kali dalam seminggu dari bulan April hingga Mei 2011, sehingga secara total dilakukan delapan kali ulangan. Pengidentifikasian lalat buah di laboratorium dilakukan dengan bantuan mikroskop stereo binokuler merek Olympus SZ 51 dan mengacu kepada pustaka Drew \& Hancock (1994), White \& Elson-Harris (1994) dan Siwi et al. (2006). Variabel penelitian adalah jumlah lalat buah Bactrocera dorsalis complex yang tertangkap dalam perangkap per dua jam dan dinyatakan dalam proporsi (\%). Untuk mengetahui signifikansi perbedaan waktu aktivitas lalat buah pada pagi, siang dan sore hari digunakan uji Kruskal-Wallis (Zar, 2010).

Kelimpahan dan Dinamika Populasi. Penelitian dilakukan pada dua pertanaman jeruk, yakni di Desa Semangat Kecamatan Merdeka dan Desa Garingging Kecamatan Merek. Luas pertanaman jeruk di Desa Garingging juga sekitar $3000 \mathrm{~m}^{2}$ dan ditanami 500 pohon jeruk. Desa Garingging terletak sekitar $1352 \mathrm{~m}$ di atas permukaan laut. Jarak antar kedua pertanaman jeruk yang menjadi lokasi penelitian lebih kurang $25 \mathrm{~km}$. Pendekatan penelitiannya didasarkan kepada modifikasi metode yang dikemukakan oleh Gupta \& Bhatia (2000), Chen et al. (2006) dan Hasyim et al. (2008). Dalam hal ini, masing-masing pada kedua pertanaman jeruk dipasang 20 perangkap berupa botol air mineral bekas. Pada kapas yang tergantung dalam perangkap ditetesi 
empat tetes metil eugenol yang berperan sebagai zat pemikat bagi lalat buah. Selanjutnya perangkap ditempatkan pada ketinggian 1,5 m dari permukaan tanah. Setelah empat hari, lalat buah yang terperangkap diambil dan dibawa ke laboratorium untuk selanjutnya disortir, diidentifikasi dan dihitung jumlahnya. Pemerangkapan lalat buah dilakukan pada setiap minggu pertama dan minggu ketiga dari bulan Maret hingga November 2011, sehingga jumlah total sampling 17 kali. Selama masa pemerangkapan lalat buah, tingkat kematangan buah jeruk di lapangan juga diamati dan dicatat. Identifikasi dan penghitungan lalat buah dilakukan sebagaimana pada metode pola aktivitas harian di atas. Variabel penelitian adalah jumlah Bactrocera dorsalis complex yang terperangkap per empat hari selama 17 minggu penelitian. Dengan data tersebut dinamika populasi Bactrocera dorsalis complex selama 17 minggu pengamatan dapat diketahui, demikian juga dengan waktu terjadinya puncak populasinya. Signifikansi perbedaan kelimpahan lalat buah pada dua pertanaman jeruk diuji dengan menggunakan uji t, sedangkan perbedaan dinamika populasinya dengan analisis korelasi tata jenjang (Zar, 2010).

Data iklim berupa suhu, jumlah hari hujan dan curah hujan dari Badan Meteorologi dan Geofisika (BMG) setempat (stasiun Kuta Gadung) dipergunakan untuk mengetahui pengaruhnya terhadap kelimpahan dan dinamika populasi lalat buah. Dalam hal ini pengujiannya dilakukan dengan menggunakan uji regresi ganda bertahap (Zar, 2010).

\section{HASIL DAN PEMBAHASAN}

Pola Aktivitas Harian. Lalat buah Bactrocera dorsalis complex memiliki pola aktivitas harian yang lebih aktif pada pagi hari jam pukul 10.00-12.00 WIB hingga siang hari 12.00-14.00 WIB (Tabel 1). Hal ini ditunjukkan oleh banyaknya lalat buah yang tertangkap pada perangkap Steiner yang diberi metil eugenol. Pada pagi hari (10.00-12.00 WIB), proporsi lalat buah yang tertangkap sebesar 29\% (167 individu) dan siang hari 28\% (159 individu). Pada pagi hari (06.00-08.00 WIB) dan sore hari (16.00-18.00 WIB) proporsi lalat buah yang aktif relatif sedikit, yakni hanya 2\% (12 individu) dan 6\% (35 individu). Berdasarkan data jumlah lalat buah yang tertangkap dapat dikemukakan puncak waktu aktif lalat buah pada pertanaman jeruk terjadi pada pagi hari pukul 10.00-12.00 WIB. Hasil uji Kruskal-Wallis menunjukkan perbedaan waktu aktif lalat buah tersebut sangat signifikan $(\mathrm{H}=26,82 ; \mathrm{P}<0,01)$.

Lebih banyaknya lalat buah yang aktif pada pagi hari hingga siang hari (10.00-14.00 WIB) dan sebaliknya relatif sedikitnya lalat buah yang aktif pada pagi hari pukul 06.00-08.00 WIB dan sore hari pukul 16.00-18.00 WIB mungkin erat kaitannya dengan sifat lalat buah yang ektoterm dan suhu lingkungan yang ada di dataran tinggi tanah Karo. Dalam hal ini agar lalat buah tersebut dapat memulai aktivitasnya (seperti menggerakkan mata, sungut, kaki, sayap hingga akhirnya terbang mencari makanan dan pasangan hidup) harus terlebih dahulu suhu ambang tubuhnya (threshold temperature) terlampaui (David \& Ananthakrishnan, 2006; Honek \& Kocourek, 1990). Menurut Liu \& Yeh (1982) dan Chen et al. (2006) suhu ambang tubuh lalat buah sekitar $18^{\circ} \mathrm{C}$. Sementara itu, menurut Badan Meteorologi dan Geofisika (BMG) setempat suhu rata-rata pada pagi hari di dataran tinggi Kabupaten Karo pada bulan April dan Mei (waktu penelitian dilaksanakan) adalah $16,9-17,3^{\circ} \mathrm{C}$, siang hari $22,9-23,5^{\circ} \mathrm{C}$ dan sore hari $19,1-19,4^{\circ} \mathrm{C}$. Jadi kondisi suhu lingkungan yang masih rendah pada pagi hari pukul 06.0008.00 WIB mungkin yang menyebabkan lebih sedikitnya proporsi lalat buah yang tertangkap pada pagi, demikian juga pada sore hari pukul 16.00-18.00 WIB jika dibandingkan dengan pada pagi hari pukul 10.00-12.00 WIB hingga siang hari pukul 12.00-14.00 WIB.

Hasil yang diperoleh pada penelitian ini menkonfirmasi hasil penelitian yang telah dilaporkan oleh Tobing et al. (2007) yang menyatakan bahwa lalat buah

Tabel 1. Proporsi lalat buah Bactrocera dorsalis complex yang tertangkap pada perangkap Steiner dari pukul 06.00-18.00 WIB pada pertanaman jeruk di Kabupaten Karo Provinsi Sumatera Utara

\begin{tabular}{cccc}
\hline No & Waktu & Jumlah tangkapan (individu) & Proporsi (\%) \\
\hline 1 & $06.00-08.00$ & 12 & 2 \\
2 & $08.00-10.00$ & 131 & 23 \\
3 & $10.00-12.00$ & 167 & 29 \\
4 & $12.00-14.00$ & 159 & 28 \\
5 & $14.00-16.00$ & 67 & 12 \\
6 & $16.00-18.00$ & 35 & 6 \\
\hline
\end{tabular}


lebih aktif pada pagi hari, akan tetapi penelitian tersebut belum mengungkapkan waktu aktifnya pada pagi hari tersebut. Sementara hasil penelitian ini menunjukkan bahwa waktu aktif lalat buah tersebut yaitu pada pukul 10.00-12.00 WIB. Selanjutnya, jika dibandingkan dengan hasil yang telah dilaporkan oleh Chen et al. (2006) relatif berbeda. Dalam hal ini Chen et al (2006) menyatakan populasi lalat buah Bactorcera dorsalis pada kebun Jambu mencapai puncaknya pada sore hari. Perbedaan hasil itu dapat dijelaskan karena Chen et al. (2006) melakukan pemerangkapan hanya pada pagi hari pukul 09.00 dan sore hari pukul 15.00 WIB. Itu berarti data lalat buah yang tertangkap pada siang hari tidak tersedia.Hal itulah mungkin yang menyebabkan mengapa hasil yang diperoleh pada penelitian ini berbeda dengan hasil yang telah dilaporkan oleh Chen et al. (2006) tersebut.

Kelimpahan dan Dinamika Populasi. Selama penelitian diperoleh lalat buah Bactrocera dorsalis complex sebanyak 2519 individu pada pertanaman jeruk di Desa Garingging dan 2160 individu di Desa Semangat
(Tabel 2). Jadi kelimpahan lalat buah pada pertanaman jeruk yang terdapat di Desa Garingging lebih banyak dibandingkan dengan yang terdapat di desa Semangat. Perbedaan kelimpahan lalat buah tersebut berdasarkan hasil uji t tidak signifikan ( $\mathrm{t}$ hitung $=1,10 ; \mathrm{P}>0,05$ ). Kelimpahan tertinggi lalat buah pada desa Garingging 340 individu terjadi pada Minggu III bulan Juni sedangkan yang terendahnya 40 individu terjadi pada Minggu I bulan Mei. Sementara itu, di Desa Semangat, kelimpahan tertingginya hanya mencapai 240 individu terjadi pada Minggu I bulan Juli dan terendahnya 30 individu terjadi juga pada Minggu I bulan Mei. Oleh karena itu, puncak kelimpahan lalat buah pada kedua pertanaman jeruk tersebut terjadi pada akhir bulan Juni hingga awal bulan Juli. Lebih lanjut dapat dikemukakan populasi lalat buah berfluktuasi seiring dengan berjalannya waktu. Dalam hal ini pada periode bulan Maret - April 2011 jumlahnya relatif lebih banyak dibandingkan pada bulan Mei yang jumlahnya menurun. Pada bulan Juni dan Juli bahkan hingga bulan Agustus jumlahnya meningkat lagi. Selanjutnya pada bulan September jumlahnya menurun lagi dan kemudian

Tabel 2. Kelimpahan lalat buah Bactrocera dorsalis Compleks per 20 perangkap dari Maret hingga November 2011 di dua pertanaman jeruk di Kabupaten Karo-Propinsi Sumatera Utara

\begin{tabular}{cllc}
\hline No & Waktu & $\begin{array}{c}\text { Kelimpahan lalat buah (ekor) } \\
\text { di Desa Garingging }\end{array}$ & $\begin{array}{c}\text { Kelimpahan lalat buah (ekor) } \\
\text { di Desa Semangat }\end{array}$ \\
\hline 1 & I. Maret & 170 & 105 \\
2 & III. Maret & 105 & 138 \\
3 & I. April & 182 & 192 \\
4 & III. April & 60 & 96 \\
5 & I. Mei & 40 & 30 \\
6 & III. Mei & 136 & 84 \\
7 & I. Juni & 304 & 146 \\
8 & III. Juni & 340 & 188 \\
9 & I. Juli & 336 & 240 \\
10 & III. Juli & 228 & 232 \\
11 & I. Agustus & 80 & 210 \\
12 & III. Agustus & 100 & 188 \\
13 & I. September & 60 & 99 \\
14 & III. September & 96 & 25 \\
15 & I. Oktober & 105 & 10 \\
16 & III. Oktober & 177 & 96 \\
17 & I. November & 188 & 81 \\
\hline Jumlah total & 2519 & 2160 \\
Rataan & Simpangan baku & 59,23 & 72,05 \\
Simp & 95,36 & \\
\hline
\end{tabular}


meningkat lagi hingga minggu I bulan November 2011. Adanya perubahan kelimpahan populasi ataupun dinamika populasi lalat buah Bactrocera spp. pada berbagai tanaman inang telah dilaporkan oleh sejumlah peneliti, diantaranya Gupta \& Bahatia (2000); Chen et al. (2006) dan Hasyim et al. (2008). Perubahan kelimpahan tersebut erat kaitannya dengan keadaan faktor lingkungan abiotik dan abiotik dimana lalat buah tersebut hidup ataupun berada (Chen et al., 2006 dan Hasyim et al., 2008).

Berdasarkan pengamatan di lapangan, tampaknya ada hubungan antara jumlah lalat buah yang tertangkap dengan fase pertumbuhan dan perkembangan tanaman jeruk atau dengan kata lain tingkat kematangan buah jeruk. Kelimpahan tertinggi diperoleh bersamaan dengan ukuran buah jeruk sebesar bola kasti dan warnanya hijau kekuningan, sedangkan kelimpahan terendah terjadi saat buah jeruk berukuran kecil sebesar kelereng dan masih berwarna kehijaun.

Ketika sampling pertama dilakukan pada Minggu I bulan Maret 2011, buah jeruk baru saja dipanen, tepatnya pada bulan Februari. Pada saat itu yang tersisa hanyalah buah jeruk yang berukuran kecil (sebesar kelereng) dan berwarna hijau. Kondisi jeruk yang sedemikian mungkin yang menjadi penyebab mengapa jumlah lalat buah yang tertangkap pada bulan Mei relatif sedikit.

Selanjutnya, pada bulan Juni dan Juli, buah jeruk di lapangan telah ada dalam ukuran yang relatif besar (sebesar bola kasti) dan lebih matang yang ditandai dengan perubahan warna dari hijau menjadi kuning. Pada kondisi jeruk yang sedemikian jumlah lalat buah yang tertangkap relatif banyak. Terjadinya hal itu mungkin erat kaitannya dengan bau ataupun aroma ester yang dihasilkan buah jeruk saat mengalami perubahan warna dari hijau ke kuning, demikian juga dengan warna kuning dari buah jeruk. Hal ini sesuai dengan apa yang dikemukakan oleh Palti \& Ausher (1983), Kalie (1992) dan juga Kusnaedi (1995), bahwa bau atau aroma ester dan visualisasi kuning dari buah jeruk sangat disukai oleh lalat buah. Kedua faktor tersebut mungkin yang menyebabkan jumlah lalat buah yang tertangkap pada bulan Juni hingga Juli 2011 pada pertanaman jeruk menjadi meningkat. Adanya hubungan antara tingkat kematangan buah dengan dinamika/fluktuasi populasi lalat buah di lapangan lebih lanjut juga telah dilaporkan oleh Gupta \& Bahatia (2000), Chen et al. (2006) dan Hasyim et al. (2008).

Pada awal Agustus 2011, buah jeruk telah dipanen pada Desa Garingging sedangkan di Desa Merdeka pada akhir Agustus 2011. Keadaan seperti itu menyebabkan buah jeruk yang tersisa di lapangan hanya buah yang berukuran kecil dengan warna hijau. Kondisi tersebut menyebabkan visualisasi kuning sebagai warna penarik bagi lalat buah, demikian juga halnya dengan tidak adanya aroma ester yang keluar dari buah jeruk menyebabkan jumlah lalat buah yang tertangkap mulai pertengahan bulan Agustus 2011 di Desa Garingging dan bulan September 2011 di Desa Semangat menjadi berkurang.

Selanjutnya, dengan berubahnya ukuran jeruk, dalam hal ini menjadi lebih besar dan mulai adanya jeruk yang berwarna hijau kekuningan pada bulan Oktober 2011, jumlah populasi lalat buah kembali meningkat. Peningkatan itu tampak terjadi mulai bulan Oktober hingga awal bulan November 2011.

Sementara itu, berdasarkan hasil uji korelasi tata jenjang dapat dikemukakan lebih lanjut bahwa kecenderungan pola fluktuasi yakni naik turunnya populasi lalat buah pada kedua pertanaman jeruk yang diselidiki (antara Desa Garingging dan Semangat) relatif sama. Hal itu ditunjukkan oleh adanya korelasi yang signifikan antara jumlah lalat buah yang tertangkap per satuan waktu pada Desa Garingging dengan jumlah yang tertangkap di Desa Semangat $\left(r_{s}=0,47 ; P<0,05\right)$ (Gambar 1). Terjadinya kesamaan pola dinamika populasi tersebut mungkin erat kaitannya dengan kesamaan waktu berbunga, pertumbuhan dan perkembangan buah jeruk, terutama masa perubahan warna buah dari hijau ke kuning bahkan waktu panen jeruk pada kedua areal pertanaman yang diselidiki relatif sama, termasuk kondisi faktor abiotik lingkungannya terutama suhu, jumlah hari hujan dan curah hujannya.

Di samping faktor tingkat kematangan buah, faktor lain yang juga turut berperan dalam mempengaruhi kelimpahan dan dinamika populasi lalat buah pada kedua lokasi penelitian adalah faktor jumlah curah hujan $\left(X_{1}\right)$ dan hari hujan $\left(X_{2}\right)$ (Tabel 3). Dalam hal ini hasil analisis regresi ganda bertahap menunjukkan hanya faktor jumlah curah hujan dan hari hujan yang secara bersama-sama berpengaruh atau berkorelasi signifikan dengan kelimpahan dan dinamika populasi lalat buah $\left(\mathrm{R}=0,79 ; \mathrm{Y}=289,34+14,23 \mathrm{X}_{1}-15,93 \mathrm{X}_{2} ; \mathrm{R}^{2}=0,62\right.$; $\mathrm{P}<0,05)$, sedangkan suhu lingkungan setempat tidak berpengaruh $\left(r=0,05 ; Y=-3,63 X_{3}+216,6 ; R^{2}=0,002\right.$; $\mathrm{P}>0,05)$. Sehubungan dengan itu, jumlah curah hujan dan hari hujan yang relatif rendah pada bulan Juni dan Juli juga perlu mendapat perhatian khusus dari petani jeruk dalam rangka pengendalian populasi lalat buah di lapangan. Adanya pengaruh faktor abiotik lingkungan seperti jumlah curah hujan dan hari hujan dalam mempengaruhi kelimpahan dan dinamika populasi lalat 


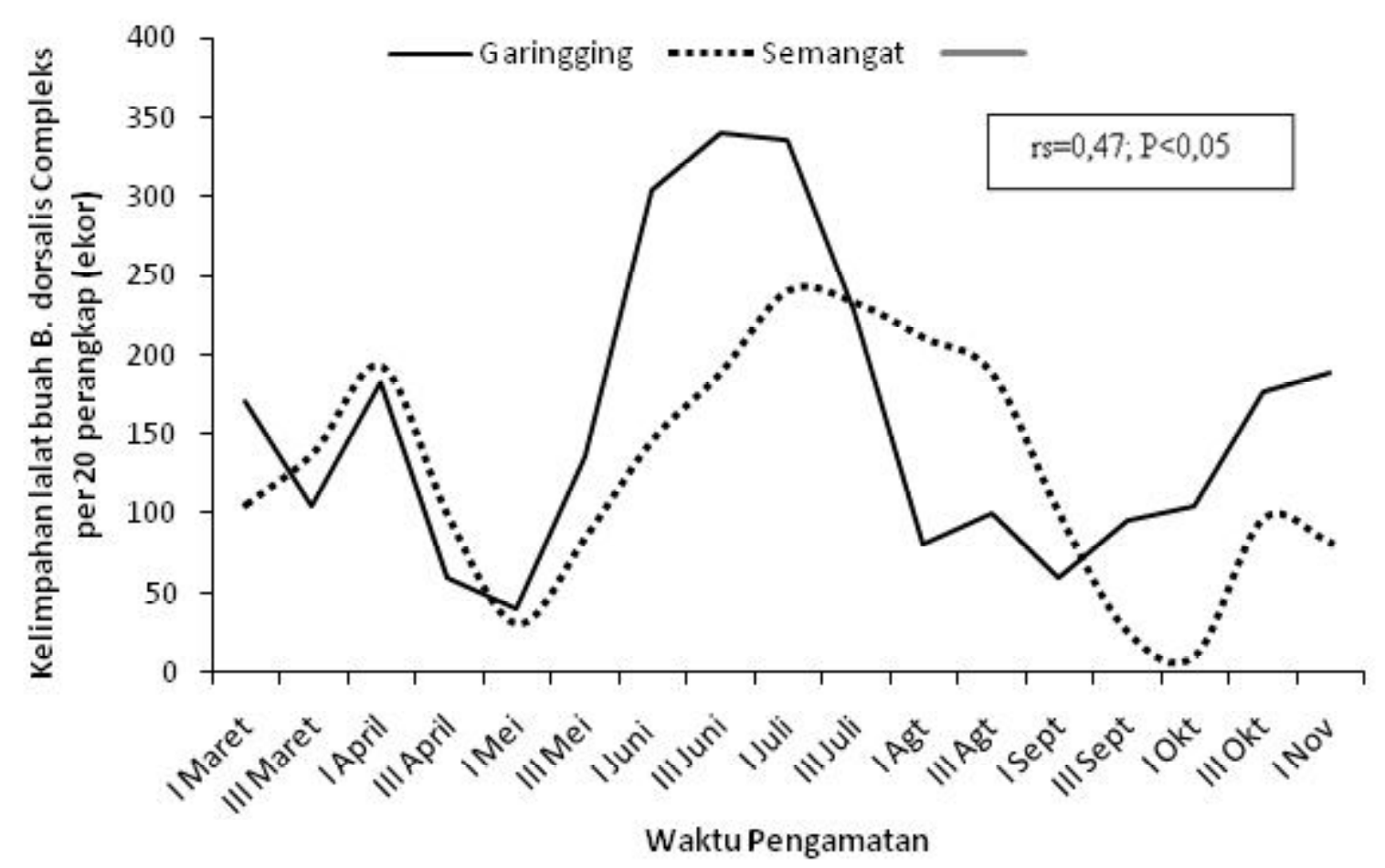

Gambar 1. Pola dinamika populasi lalat buah Bactrocera dorsalis complex pada pertanaman jeruk di dua Desa di Kabupaten Karo dari bulan Maret hingga November 2011.

Tabel 3. Faktor iklim (curah hujan, hari hujan dan suhu) serta kelimpahan rata-rata per bulan lalat buah Bactrocera dorsalis complex yang tertangkap dari bulan Maret hingga November 2011 di Kabupaten Karo Provinsi Sumatera Utara

\begin{tabular}{lcccc}
\hline Waktu & Curah Hujan $(\mathrm{ml})$ & Hari Hujan $(\mathrm{d})$ & Suhu $\left({ }^{\circ} \mathrm{C}\right)$ & Jumlah Lalat Buah (Ekor) \\
\hline Maret & 4,7 & 17 & 19 & 129 \\
April & 6,8 & 15 & 19,1 & 133 \\
Mei & 2,6 & 13 & 19,5 & 73 \\
Juni & 2,1 & 9 & 19,1 & 245 \\
Juli & 0,4 & 2 & 18,9 & 259 \\
Agustus & 11,1 & 19 & 18,6 & 145 \\
September & 3,8 & 13 & 18,7 & 70 \\
Oktober & 5,8 & 18 & 18,7 & 96 \\
November & 7,6 & 17 & 21,6 & 134 \\
\hline
\end{tabular}

buah Bactrocera spp. telah juga dilaporkan oleh Chen et al. (2006) dan Hasyim et al. (2008).

\section{SIMPULAN}

Lalat buah Bactrocera dorsalis complex pada pertanaman jeruk di dataran tinggi Kabupaten KaroProvinsi Sumatera Utara lebih aktif pada pagi hari pukul 10.00-12.00 WIB. Puncak kelimpahan populasinya terjadi pada bulan Juni hingga Juli bersamaan dengan terjadinya masa pematangan buah jeruk dan relatif sedikitnya jumlah hari hujan dan curah hujan. Dinamika populasi lalat buah Bactrocera dorsalis complex pada dua lokasi pertanaman jeruk yang diselidiki menunjukkan pola yang relatif sama. Jumlah hari hujan dan curah hujan setempat secara bersama-sama berkorelasi negatif terhadap kelimpahan dan dinamika populasi lalat buah. 


\section{SANWACANA}

Tim Peneliti mengucapkan terimakasih kepada Ditjen Dikti-DP2M Dikti Depdiknas yang telah mendanai pelaksanaan penelitian ini dengan Surat Perjanjian Hibah Penugasan Penelitian Fundamental No.199/SP2H/PL/ Dit.Litabmas/IV/2011 tanggal 14 April 2011. Demikian juga kepada Parningotan Sijabat pada BMG-Stasiun Klimatologi Kuta Gadung Kabupaten Karo yang telah bersedia menyediakan data suhu, jumlah hari hujan dan curah hujan.

\section{DAFTAR PUSTAKA}

Asokan R, Kumar NKK \& Verghese A. 2007. Molecular identification of fruit flies Bactrocera spp. (Diptera: Tephritidae) using mitochondrial cytochrome oxidase I. Current Science 93 (12): 1668-1669.

Drew RAI \& Hancock DL. 1994. The Bactrocera dorsalis complex of fruit flies (Diptera: Tephritidae: Dacinae) in Asia. Bulletin of Entomological Research Suppl. (2): 1-68.

Chen CC, Dong YJ, Lie CT, Lin KY \& Cheng LL. 2006. Movement of the oriental fruit fly, Bactrocera dorsalis (Hendel) (Diptera: Tephritidae) in a Guava orchard with special reference to its population changes. Formosan Entomol. 26: 143159.

David BV \& Ananthakrishnan TN. 2006. General and Applied Entomology. Tata McGraw-Hill Publishing Company Limited, New Delhi.

Gupta D \& Bahatia R. 2000. Population fluctuations of fruit flies, Bactrocera spp. in sub mountainous mango and guava orchards. J. Appl. Hort. 2(1): 47-49.

Hasyim A, Muryati \& de Kogel WJ. 2008. Population fluctuation of adult males of the fruit fly Bactrocera tau Walker (Diptera: Tephritidae) in passion fruit orchards in relation to abiotic factors and sanitation. Indonesian Journal of Agricultural Sciences 9(1): 29-33.

Honek A \& Kocourek F. 1990. Temperature and development time in insects: A general relationship between thermal constants. Zool. Jb. Syst. 117: 401-439.
Hutasoit K. 2004. Petani dan Kebun Jeruk. http:// www.mediaindo.12.co.id./berita.asp (Diakses 4 Maret 2010).

Kalie MB. 1992. Mengatasi Buah Rontok, Busuk dan Berulat. Penerbar Swadaya, Jakarta.

Kardinan A. 2003. Tanaman Pengendali Lalat Buah. Agromedia Pustaka, Jakarta.

Kusnaedi.1995. Pengendalian Hama Tanpa Pestisida. Penebar Swadaya, Jakarta.

Liu YC \& Yeh CC. 1982. Population fluctuation of oriental fruit fly Dacus dorsalis Hendel in sterile fly release and control area. Chinese J. Entomol. 2: 57-70.

Manik L \& Bangun A. 2004. Sumut Terima Alokasi Terbesar, Deptan Siapkan Rp.1 Miliar.Kendalikan Hama Lalat Buah. http/www.sebayak.org./ berita.php.id (Diakses 4 Maret 2010).

Manurung B, Witsack W, Mehner S, Grüntzig M \& Fuchs E. 2004. The epidemiology of Wheat dwarf virus in relation to occurrence of the leafhopper Psammotettix alienus in Middle-Germany. Virus Research 100: 109-113.

Manurung B, Witsack W, Mehner S, Grüntzig M \& Fuchs E. 2005. Studies on biology and population dynamics of the leafhopper Psammotettix alienus Dahlb. (Homoptera:Auchenorrhyncha) as vector of wheat dwarf virus (WDV) in Saxony-Anhalt, Germany. Journal of Plant Diseases and Protection 112 (5): 497-50

Palti J \& Ausher R. 1983. Advisory Work in Crop Pest and Disease Management. Springer-Verlag, New York.

Putra NS. 1997. Hama Lalat Buah dan Pengendalianya. Penerbit Kanisius, Yogjakarta.

Shehata NF, Younes MWF \& Mahmoud YA. 2008. Biological studies on the peach fruit fly Bactrocera zonata (Saunders) in Egypt. Journal of Applied Sciences Research 4(9): 1103-1106.

Siwi SS, Hidayat P \& Suputa. 2006. Taksonomi dan Bioekologi Lalat Buah Penting di Indonesia (Diptera: Tephritidae). BB Biogen \& Dept. Agriculture, Fisheries \& Forestry Australia, Bogor. 
Tobing MC, Marheni, Mariati \& Sipayung R. 2007. Pengaruh metil eugenol dalam pengendalian lalat buah (Bactrocera dorsalis) pada pertanaman jeruk. Jurnal Natur Indonesia 9 (2): 127-130.
White IM \& Elson-Harris MM. 1994. Fruit Flies of Economic Significance, Their Identification and Bionomics. CAB International, WallingfordUK.

Zar JH. 2010. Biostatistical Analysis. $5^{\text {th }}$ Edition. Prentice-Hall International, Inc., New Jersey. 


\title{
POLA AKTIVITAS HARIAN DAN DINAMIKA POPULASI LALAT BUAH BACTROCERA DORSALIS COMPLEX PADA PERTANAMAN JERUK DI DATARAN TINGGI KABUPATEN KARO PROVINSI SUMATERA UTARA
}

\author{
Binari Manurung, Puji Prastowo \& Emmi Ebrina Tarigan \\ Jurusan Biologi-Universitas Negeri Medan, Jln. Williem Iskandar Psr. V Medan Estate. \\ E-mail: binari44@hotmail.com
}

\begin{abstract}
Daily activity pattern and population dynamic of fruit fly Bactrocera dorsalis complex on citrus plantation at highland Karo district North Sumatera Province. The fruit fly Bactrocera dorsalis complex is important pest on citrus plantation at highland Karo district North Sumatera Province. The studies with the aim to find out its daily activity pattern and population dynamic on citrus plantation have been done. Fruit flies were collected by water bottle trap with methyl eugenol attractant. Sampling for daily activity pattern was done per two hours for two months (April to May 2011) from 06.00 a.m until 18.00 p.m. Meanwhile, population dynamic study was conducted on two citrus plantations per four days for nine months (March to November 2011) in the first and third week of each month. The research result showed that B.dorsalis complex was more active during morning at 10.00 to $12.00 \mathrm{a}$.m. The peak abundance of fruit fly occurred at the end of June until beginning of July. The peak population coincided with the ripening period of fruits, low number of rainy $(\mathrm{d})$ and rainfall $(\mathrm{mm})$ in June and July periods. There was a significant correlation between number of rainy day and rainfall with fruit flies caught per month $(\mathrm{R}=0.79 ; \mathrm{Y}=$ $\left.289.34+14.23 \mathrm{X}_{1}-15.93 \mathrm{X}_{2} ; \mathrm{R}^{2}=0.62 ; \mathrm{P}<0.05\right)$. The pattern of fruit fly fluctuation in two citrus plantations was similar $\left(\mathrm{r}_{\mathrm{s}}=0.47\right.$; $\mathrm{P}<0.05)$.
\end{abstract}

Keywords: fruit fly Bactrocera dorsalis complex, daily activity pattern, population dynamic

\begin{abstract}
ABSTRAK
Pola aktivitas harian dan dinamika populasi lalat buah Bactrocera dorsalis complex pada pertanaman jeruk di dataran tinggi Kabupaten Karo Provinsi Sumatera Utara. Lalat buah Bactrocera dorsalis complex merupakan hama penting tanaman jeruk di dataran tinggi Kabupaten Karo-Provinsi Sumatera Utara. Suatu penelitian yang bertujuan untuk mengkaji pola waktu aktivitas harian dan dinamika populasinya telah dilakukan. Sampel lalat buah ditangkap dengan menggunakan perangkap Steiner (botol bekas air mineral) yang diberi zat pemikat metil eugenol. Sampling untuk kajian pola aktivitas harian dilakukan per dua jam selama dua bulan ( April -Mei 2011) dari pukul 06.00-18.00 WIB, sedangkan untuk dinamika populasi dilakukan pada dua pertanaman jeruk per empat hari selama sembilan bulan (Maret 2011-November 2011) yakni pada minggu I dan III setiap bulannya. Hasil penelitian menunjukkan B. dorsalis complex lebih aktif pada pagi hari pukul 10.00-12.00 WIB. Kelimpahan puncak terjadi pada akhir Juni hingga awal Juli. Puncak populasi terjadi bersamaan dengan masa pematangan buah jeruk, rendahnya jumlah hari hujan dan curah hujan pada bulan Juni dan Juli. Terdapat hubungan yang signifikan antara jumlah hari hujan dan curah hujan dengan jumlah lalat buah yang tertangkap setiap bulan $\left(\mathrm{R}=0,79 ; \mathrm{Y}=289,34+14,23 \mathrm{X}_{1}\right.$ $\left.15,93 \mathrm{X}_{2} ; \mathrm{R}^{2}=0,62 ; \mathrm{P}<0.05\right)$. Dinamika populasi lalat buah pada dua lokasi pertanaman jeruk yang diselidiki menunjukkan pola yang relatif sama $\left(\mathrm{r}_{\mathrm{s}}=0.47 ; \mathrm{P}<0.05\right)$.
\end{abstract}

Kata kunci: lalat buah Bactrocera dorsalis complex, pola aktivitas harian, dinamika populasi

\section{PENDAHULUAN}

Kabupaten Karo yang berada di daerah pegunungan pada ketinggian $1400 \mathrm{~m}$ di atas permukaan laut merupakan salah satu pusat produksi buah-buahan, khususnya jeruk manis (Citrus sp.). Namun produksi jeruk dari Kabupaten tersebut sejak tahun 2003 telah mengalami penurunan yang sangat drastis. Hal itu terjadi karena buah tanaman jeruk yang berada di daerah ini diserang oleh lalat buah Bactrocera sp. (Diptera: Tephritidae). Menurut Hasyim et al. (2008) sebagai salah satu serangga hama penting tanaman hortikultura di daerah tropis dan subtropis, lalat buah meletakkan telurnya di bawah kulit buah, kemudian menetas menjadi larva dan selanjutnya mengkonsumsi daging buah. Buah yang terserang lalat buah akan menjadi lebih cepat busuk dan jatuh dari pohonnya sebelum waktunya (Hutasoit, 2004). 
Hama lalat buah diperkirakan telah merusak sekitar 17.000 hektar tanaman jeruk yang berada di daerah Kabupaten Karo dan menyebabkan produksi per hektarnya mengalami penurunan yang drastis menjadi 20 ton dari sebelumnya 60 ton. Bahkan kualitas buah jeruk yang dihasilkannya juga amat buruk sehingga harga jualnya di tingkat petani turun hingga 50\% (Manik \& Bangun, 2004).

Surat Kabar Harian Medan Bisnis pada 31 Mei 2004 memberitakan bahwa lalat buah yang menyerang tanaman jeruk yang berada di dataran tinggi provinsi Sumatra secara signifikan mampu mengurangi produksi sampai $70 \%$. Sehubungan dengan masalah tersebut pada bulan Mei 2004 gerakan pengendalian massal lalat buah telah dicanangkan, ditandai dengan pemukulan gong oleh Menteri Pertanian Republik Indonesia.

Salah satu langkah penting yang harus dilakukan dalam rangka monitoring dan pengendalian lalat buah yang menyerang tanaman jeruk adalah memahami bioekologi dari lalat buah tersebut. Sejumlah hasil penelitian tentang bioekologi lalat buah Bactrocera spp. telah dilaporkan oleh beberapa peneliti. Misalnya, Shehata et al. (2008) tentang biologi perkembangannya; Hasyim et al. (2008) tentang fluktuasi populasinya, Chen et al. (2006) perihal migrasi dan perubahan populasinya; dan Asokan et al. (2007) tentang biologi molekularnya.

Informasi mengenai bioekologi lalat buah Bactrocera spp. yang menyerang tanaman jeruk di Kabupaten Karo Sumatera Utara masih sangat terbatas. Penelitian yang telah dilakukan diantaranya masih berkaitan dengan keanekaragaman spesies dan pengaruh metil eugenol dalam pengendalian populasinya. Spesies lalat buah yang menyerang tanaman jeruk adalah Bactrocera dorsalis dan metil eugenol dengan menggunakan perangkap Steiner dapat dipergunakan untuk mengendalikan populasinya (Tobing et al., 2007).

Penelitian bertujuan untuk mengetahui pola aktivitas harian, kelimpahan dan dinamika populasi lalat buah dalam hubungannya dengan tingkat kematangan buah jeruk, perbedaan kelimpahan dan pola dinamika populasi lalat buah pada dua pertanaman jeruk serta hubungan antara faktor lingkungan (iklim) dengan kelimpahan/dinamika populasi lalat buah. Pemahaman tentang hal ini mempunyai kontribusi penting dalam monitoring ataupun pengendalian populasi lalat buah di lapangan. Kepentingan data semacam itu untuk monitoring dan pengendalian populasi serangga di lapangan saat menjadi hama pertanian telah dilaporkan oleh Manurung et al. (2004 \& 2005).

\section{METODE PENELITIAN}

Pola Aktivitas Harian. Penelitian dilakukan pada pertanaman jeruk manis di Desa Semangat Kecamatan Merdeka yang terletak pada ketinggian sekitar $1360 \mathrm{~m}$ di atas permukaan laut. Luas pertanaman jeruk tersebut $3000 \mathrm{~m}^{2}$ dan terdapat 500 pohon jeruk. Tanaman jeruk telah berumur sekitar 7 (tujuh) tahun. Pemerangkapan lalat buah dilakukan dengan menggunakan tipe perangkap Steiner yang telah dimodifikasi, yakni berupa botol bekas air mineral berukuran $1500 \mathrm{ml}$ yang salah satu bagian ujungnya diubah sedemikian rupa sehingga dapat berperan sebagai pintu masuk bagi lalat buah (Putra, 1997; Gupta \& Bhatia, 2000; Kardinan, 2003 \& Hasyim et al., 2008). Pada kawat yang terdapat pada bagian dalam botol digantungkan kapas sebesar ibu jari dan ditetesi zat pemikat metil eugenol sebanyak empat tetes. Perangkap digantung pada pohon jeruk pada ketinggian 1,5 meter dari permukaan tanah. Jumlah perangkap yang digunakan sebanyak 20 buah. Pemasangan perangkap berlangsung dari pukul 06.00 hingga pukul 18.00 WIB. Pemerangkapan dilakukan satu kali dalam seminggu dari bulan April hingga Mei 2011, sehingga secara total dilakukan delapan kali ulangan. Pengidentifikasian lalat buah di laboratorium dilakukan dengan bantuan mikroskop stereo binokuler merek Olympus SZ 51 dan mengacu kepada pustaka Drew \& Hancock (1994), White \& Elson-Harris (1994) dan Siwi et al. (2006). Variabel penelitian adalah jumlah lalat buah Bactrocera dorsalis complex yang tertangkap dalam perangkap per dua jam dan dinyatakan dalam proporsi (\%). Untuk mengetahui signifikansi perbedaan waktu aktivitas lalat buah pada pagi, siang dan sore hari digunakan uji Kruskal-Wallis (Zar, 2010).

Kelimpahan dan Dinamika Populasi. Penelitian dilakukan pada dua pertanaman jeruk, yakni di Desa Semangat Kecamatan Merdeka dan Desa Garingging Kecamatan Merek. Luas pertanaman jeruk di Desa Garingging juga sekitar $3000 \mathrm{~m}^{2}$ dan ditanami 500 pohon jeruk. Desa Garingging terletak sekitar $1352 \mathrm{~m}$ di atas permukaan laut. Jarak antar kedua pertanaman jeruk yang menjadi lokasi penelitian lebih kurang $25 \mathrm{~km}$. Pendekatan penelitiannya didasarkan kepada modifikasi metode yang dikemukakan oleh Gupta \& Bhatia (2000), Chen et al. (2006) dan Hasyim et al. (2008). Dalam hal ini, masing-masing pada kedua pertanaman jeruk dipasang 20 perangkap berupa botol air mineral bekas. Pada kapas yang tergantung dalam perangkap ditetesi 
empat tetes metil eugenol yang berperan sebagai zat pemikat bagi lalat buah. Selanjutnya perangkap ditempatkan pada ketinggian 1,5 m dari permukaan tanah. Setelah empat hari, lalat buah yang terperangkap diambil dan dibawa ke laboratorium untuk selanjutnya disortir, diidentifikasi dan dihitung jumlahnya. Pemerangkapan lalat buah dilakukan pada setiap minggu pertama dan minggu ketiga dari bulan Maret hingga November 2011, sehingga jumlah total sampling 17 kali. Selama masa pemerangkapan lalat buah, tingkat kematangan buah jeruk di lapangan juga diamati dan dicatat. Identifikasi dan penghitungan lalat buah dilakukan sebagaimana pada metode pola aktivitas harian di atas. Variabel penelitian adalah jumlah Bactrocera dorsalis complex yang terperangkap per empat hari selama 17 minggu penelitian. Dengan data tersebut dinamika populasi Bactrocera dorsalis complex selama 17 minggu pengamatan dapat diketahui, demikian juga dengan waktu terjadinya puncak populasinya. Signifikansi perbedaan kelimpahan lalat buah pada dua pertanaman jeruk diuji dengan menggunakan uji t, sedangkan perbedaan dinamika populasinya dengan analisis korelasi tata jenjang (Zar, 2010).

Data iklim berupa suhu, jumlah hari hujan dan curah hujan dari Badan Meteorologi dan Geofisika (BMG) setempat (stasiun Kuta Gadung) dipergunakan untuk mengetahui pengaruhnya terhadap kelimpahan dan dinamika populasi lalat buah. Dalam hal ini pengujiannya dilakukan dengan menggunakan uji regresi ganda bertahap (Zar, 2010).

\section{HASIL DAN PEMBAHASAN}

Pola Aktivitas Harian. Lalat buah Bactrocera dorsalis complex memiliki pola aktivitas harian yang lebih aktif pada pagi hari jam pukul 10.00-12.00 WIB hingga siang hari 12.00-14.00 WIB (Tabel 1). Hal ini ditunjukkan oleh banyaknya lalat buah yang tertangkap pada perangkap Steiner yang diberi metil eugenol. Pada pagi hari (10.00-12.00 WIB), proporsi lalat buah yang tertangkap sebesar 29\% (167 individu) dan siang hari 28\% (159 individu). Pada pagi hari (06.00-08.00 WIB) dan sore hari (16.00-18.00 WIB) proporsi lalat buah yang aktif relatif sedikit, yakni hanya 2\% (12 individu) dan 6\% (35 individu). Berdasarkan data jumlah lalat buah yang tertangkap dapat dikemukakan puncak waktu aktif lalat buah pada pertanaman jeruk terjadi pada pagi hari pukul 10.00-12.00 WIB. Hasil uji Kruskal-Wallis menunjukkan perbedaan waktu aktif lalat buah tersebut sangat signifikan $(\mathrm{H}=26,82 ; \mathrm{P}<0,01)$.

Lebih banyaknya lalat buah yang aktif pada pagi hari hingga siang hari (10.00-14.00 WIB) dan sebaliknya relatif sedikitnya lalat buah yang aktif pada pagi hari pukul 06.00-08.00 WIB dan sore hari pukul 16.00-18.00 WIB mungkin erat kaitannya dengan sifat lalat buah yang ektoterm dan suhu lingkungan yang ada di dataran tinggi tanah Karo. Dalam hal ini agar lalat buah tersebut dapat memulai aktivitasnya (seperti menggerakkan mata, sungut, kaki, sayap hingga akhirnya terbang mencari makanan dan pasangan hidup) harus terlebih dahulu suhu ambang tubuhnya (threshold temperature) terlampaui (David \& Ananthakrishnan, 2006; Honek \& Kocourek, 1990). Menurut Liu \& Yeh (1982) dan Chen et al. (2006) suhu ambang tubuh lalat buah sekitar $18^{\circ} \mathrm{C}$. Sementara itu, menurut Badan Meteorologi dan Geofisika (BMG) setempat suhu rata-rata pada pagi hari di dataran tinggi Kabupaten Karo pada bulan April dan Mei (waktu penelitian dilaksanakan) adalah $16,9-17,3^{\circ} \mathrm{C}$, siang hari $22,9-23,5^{\circ} \mathrm{C}$ dan sore hari $19,1-19,4^{\circ} \mathrm{C}$. Jadi kondisi suhu lingkungan yang masih rendah pada pagi hari pukul 06.0008.00 WIB mungkin yang menyebabkan lebih sedikitnya proporsi lalat buah yang tertangkap pada pagi, demikian juga pada sore hari pukul 16.00-18.00 WIB jika dibandingkan dengan pada pagi hari pukul 10.00-12.00 WIB hingga siang hari pukul 12.00-14.00 WIB.

Hasil yang diperoleh pada penelitian ini menkonfirmasi hasil penelitian yang telah dilaporkan oleh Tobing et al. (2007) yang menyatakan bahwa lalat buah

Tabel 1. Proporsi lalat buah Bactrocera dorsalis complex yang tertangkap pada perangkap Steiner dari pukul 06.00-18.00 WIB pada pertanaman jeruk di Kabupaten Karo Provinsi Sumatera Utara

\begin{tabular}{cccc}
\hline No & Waktu & Jumlah tangkapan (individu) & Proporsi (\%) \\
\hline 1 & $06.00-08.00$ & 12 & 2 \\
2 & $08.00-10.00$ & 131 & 23 \\
3 & $10.00-12.00$ & 167 & 29 \\
4 & $12.00-14.00$ & 159 & 28 \\
5 & $14.00-16.00$ & 67 & 12 \\
6 & $16.00-18.00$ & 35 & 6 \\
\hline
\end{tabular}


lebih aktif pada pagi hari, akan tetapi penelitian tersebut belum mengungkapkan waktu aktifnya pada pagi hari tersebut. Sementara hasil penelitian ini menunjukkan bahwa waktu aktif lalat buah tersebut yaitu pada pukul 10.00-12.00 WIB. Selanjutnya, jika dibandingkan dengan hasil yang telah dilaporkan oleh Chen et al. (2006) relatif berbeda. Dalam hal ini Chen et al (2006) menyatakan populasi lalat buah Bactorcera dorsalis pada kebun Jambu mencapai puncaknya pada sore hari. Perbedaan hasil itu dapat dijelaskan karena Chen et al. (2006) melakukan pemerangkapan hanya pada pagi hari pukul 09.00 dan sore hari pukul 15.00 WIB. Itu berarti data lalat buah yang tertangkap pada siang hari tidak tersedia.Hal itulah mungkin yang menyebabkan mengapa hasil yang diperoleh pada penelitian ini berbeda dengan hasil yang telah dilaporkan oleh Chen et al. (2006) tersebut.

Kelimpahan dan Dinamika Populasi. Selama penelitian diperoleh lalat buah Bactrocera dorsalis complex sebanyak 2519 individu pada pertanaman jeruk di Desa Garingging dan 2160 individu di Desa Semangat
(Tabel 2). Jadi kelimpahan lalat buah pada pertanaman jeruk yang terdapat di Desa Garingging lebih banyak dibandingkan dengan yang terdapat di desa Semangat. Perbedaan kelimpahan lalat buah tersebut berdasarkan hasil uji t tidak signifikan ( $\mathrm{t}$ hitung $=1,10 ; \mathrm{P}>0,05$ ). Kelimpahan tertinggi lalat buah pada desa Garingging 340 individu terjadi pada Minggu III bulan Juni sedangkan yang terendahnya 40 individu terjadi pada Minggu I bulan Mei. Sementara itu, di Desa Semangat, kelimpahan tertingginya hanya mencapai 240 individu terjadi pada Minggu I bulan Juli dan terendahnya 30 individu terjadi juga pada Minggu I bulan Mei. Oleh karena itu, puncak kelimpahan lalat buah pada kedua pertanaman jeruk tersebut terjadi pada akhir bulan Juni hingga awal bulan Juli. Lebih lanjut dapat dikemukakan populasi lalat buah berfluktuasi seiring dengan berjalannya waktu. Dalam hal ini pada periode bulan Maret - April 2011 jumlahnya relatif lebih banyak dibandingkan pada bulan Mei yang jumlahnya menurun. Pada bulan Juni dan Juli bahkan hingga bulan Agustus jumlahnya meningkat lagi. Selanjutnya pada bulan September jumlahnya menurun lagi dan kemudian

Tabel 2. Kelimpahan lalat buah Bactrocera dorsalis Compleks per 20 perangkap dari Maret hingga November 2011 di dua pertanaman jeruk di Kabupaten Karo-Propinsi Sumatera Utara

\begin{tabular}{cllc}
\hline No & Waktu & $\begin{array}{c}\text { Kelimpahan lalat buah (ekor) } \\
\text { di Desa Garingging }\end{array}$ & $\begin{array}{c}\text { Kelimpahan lalat buah (ekor) } \\
\text { di Desa Semangat }\end{array}$ \\
\hline 1 & I. Maret & 170 & 105 \\
2 & III. Maret & 105 & 138 \\
3 & I. April & 182 & 192 \\
4 & III. April & 60 & 96 \\
5 & I. Mei & 40 & 30 \\
6 & III. Mei & 136 & 84 \\
7 & I. Juni & 304 & 146 \\
8 & III. Juni & 340 & 188 \\
9 & I. Juli & 336 & 240 \\
10 & III. Juli & 228 & 232 \\
11 & I. Agustus & 80 & 210 \\
12 & III. Agustus & 100 & 188 \\
13 & I. September & 60 & 99 \\
14 & III. September & 96 & 25 \\
15 & I. Oktober & 105 & 10 \\
16 & III. Oktober & 177 & 96 \\
17 & I. November & 188 & 81 \\
\hline Jumlah total & 2519 & 2160 \\
Rataan & Simpangan baku & 59,23 & 72,05 \\
Simp & 95,36 & \\
\hline
\end{tabular}


meningkat lagi hingga minggu I bulan November 2011. Adanya perubahan kelimpahan populasi ataupun dinamika populasi lalat buah Bactrocera spp. pada berbagai tanaman inang telah dilaporkan oleh sejumlah peneliti, diantaranya Gupta \& Bahatia (2000); Chen et al. (2006) dan Hasyim et al. (2008). Perubahan kelimpahan tersebut erat kaitannya dengan keadaan faktor lingkungan abiotik dan abiotik dimana lalat buah tersebut hidup ataupun berada (Chen et al., 2006 dan Hasyim et al., 2008).

Berdasarkan pengamatan di lapangan, tampaknya ada hubungan antara jumlah lalat buah yang tertangkap dengan fase pertumbuhan dan perkembangan tanaman jeruk atau dengan kata lain tingkat kematangan buah jeruk. Kelimpahan tertinggi diperoleh bersamaan dengan ukuran buah jeruk sebesar bola kasti dan warnanya hijau kekuningan, sedangkan kelimpahan terendah terjadi saat buah jeruk berukuran kecil sebesar kelereng dan masih berwarna kehijaun.

Ketika sampling pertama dilakukan pada Minggu I bulan Maret 2011, buah jeruk baru saja dipanen, tepatnya pada bulan Februari. Pada saat itu yang tersisa hanyalah buah jeruk yang berukuran kecil (sebesar kelereng) dan berwarna hijau. Kondisi jeruk yang sedemikian mungkin yang menjadi penyebab mengapa jumlah lalat buah yang tertangkap pada bulan Mei relatif sedikit.

Selanjutnya, pada bulan Juni dan Juli, buah jeruk di lapangan telah ada dalam ukuran yang relatif besar (sebesar bola kasti) dan lebih matang yang ditandai dengan perubahan warna dari hijau menjadi kuning. Pada kondisi jeruk yang sedemikian jumlah lalat buah yang tertangkap relatif banyak. Terjadinya hal itu mungkin erat kaitannya dengan bau ataupun aroma ester yang dihasilkan buah jeruk saat mengalami perubahan warna dari hijau ke kuning, demikian juga dengan warna kuning dari buah jeruk. Hal ini sesuai dengan apa yang dikemukakan oleh Palti \& Ausher (1983), Kalie (1992) dan juga Kusnaedi (1995), bahwa bau atau aroma ester dan visualisasi kuning dari buah jeruk sangat disukai oleh lalat buah. Kedua faktor tersebut mungkin yang menyebabkan jumlah lalat buah yang tertangkap pada bulan Juni hingga Juli 2011 pada pertanaman jeruk menjadi meningkat. Adanya hubungan antara tingkat kematangan buah dengan dinamika/fluktuasi populasi lalat buah di lapangan lebih lanjut juga telah dilaporkan oleh Gupta \& Bahatia (2000), Chen et al. (2006) dan Hasyim et al. (2008).

Pada awal Agustus 2011, buah jeruk telah dipanen pada Desa Garingging sedangkan di Desa Merdeka pada akhir Agustus 2011. Keadaan seperti itu menyebabkan buah jeruk yang tersisa di lapangan hanya buah yang berukuran kecil dengan warna hijau. Kondisi tersebut menyebabkan visualisasi kuning sebagai warna penarik bagi lalat buah, demikian juga halnya dengan tidak adanya aroma ester yang keluar dari buah jeruk menyebabkan jumlah lalat buah yang tertangkap mulai pertengahan bulan Agustus 2011 di Desa Garingging dan bulan September 2011 di Desa Semangat menjadi berkurang.

Selanjutnya, dengan berubahnya ukuran jeruk, dalam hal ini menjadi lebih besar dan mulai adanya jeruk yang berwarna hijau kekuningan pada bulan Oktober 2011, jumlah populasi lalat buah kembali meningkat. Peningkatan itu tampak terjadi mulai bulan Oktober hingga awal bulan November 2011.

Sementara itu, berdasarkan hasil uji korelasi tata jenjang dapat dikemukakan lebih lanjut bahwa kecenderungan pola fluktuasi yakni naik turunnya populasi lalat buah pada kedua pertanaman jeruk yang diselidiki (antara Desa Garingging dan Semangat) relatif sama. Hal itu ditunjukkan oleh adanya korelasi yang signifikan antara jumlah lalat buah yang tertangkap per satuan waktu pada Desa Garingging dengan jumlah yang tertangkap di Desa Semangat $\left(r_{s}=0,47 ; P<0,05\right)$ (Gambar 1). Terjadinya kesamaan pola dinamika populasi tersebut mungkin erat kaitannya dengan kesamaan waktu berbunga, pertumbuhan dan perkembangan buah jeruk, terutama masa perubahan warna buah dari hijau ke kuning bahkan waktu panen jeruk pada kedua areal pertanaman yang diselidiki relatif sama, termasuk kondisi faktor abiotik lingkungannya terutama suhu, jumlah hari hujan dan curah hujannya.

Di samping faktor tingkat kematangan buah, faktor lain yang juga turut berperan dalam mempengaruhi kelimpahan dan dinamika populasi lalat buah pada kedua lokasi penelitian adalah faktor jumlah curah hujan $\left(X_{1}\right)$ dan hari hujan $\left(X_{2}\right)$ (Tabel 3). Dalam hal ini hasil analisis regresi ganda bertahap menunjukkan hanya faktor jumlah curah hujan dan hari hujan yang secara bersama-sama berpengaruh atau berkorelasi signifikan dengan kelimpahan dan dinamika populasi lalat buah $\left(\mathrm{R}=0,79 ; \mathrm{Y}=289,34+14,23 \mathrm{X}_{1}-15,93 \mathrm{X}_{2} ; \mathrm{R}^{2}=0,62\right.$; $\mathrm{P}<0,05)$, sedangkan suhu lingkungan setempat tidak berpengaruh $\left(r=0,05 ; Y=-3,63 X_{3}+216,6 ; R^{2}=0,002\right.$; $\mathrm{P}>0,05)$. Sehubungan dengan itu, jumlah curah hujan dan hari hujan yang relatif rendah pada bulan Juni dan Juli juga perlu mendapat perhatian khusus dari petani jeruk dalam rangka pengendalian populasi lalat buah di lapangan. Adanya pengaruh faktor abiotik lingkungan seperti jumlah curah hujan dan hari hujan dalam mempengaruhi kelimpahan dan dinamika populasi lalat 


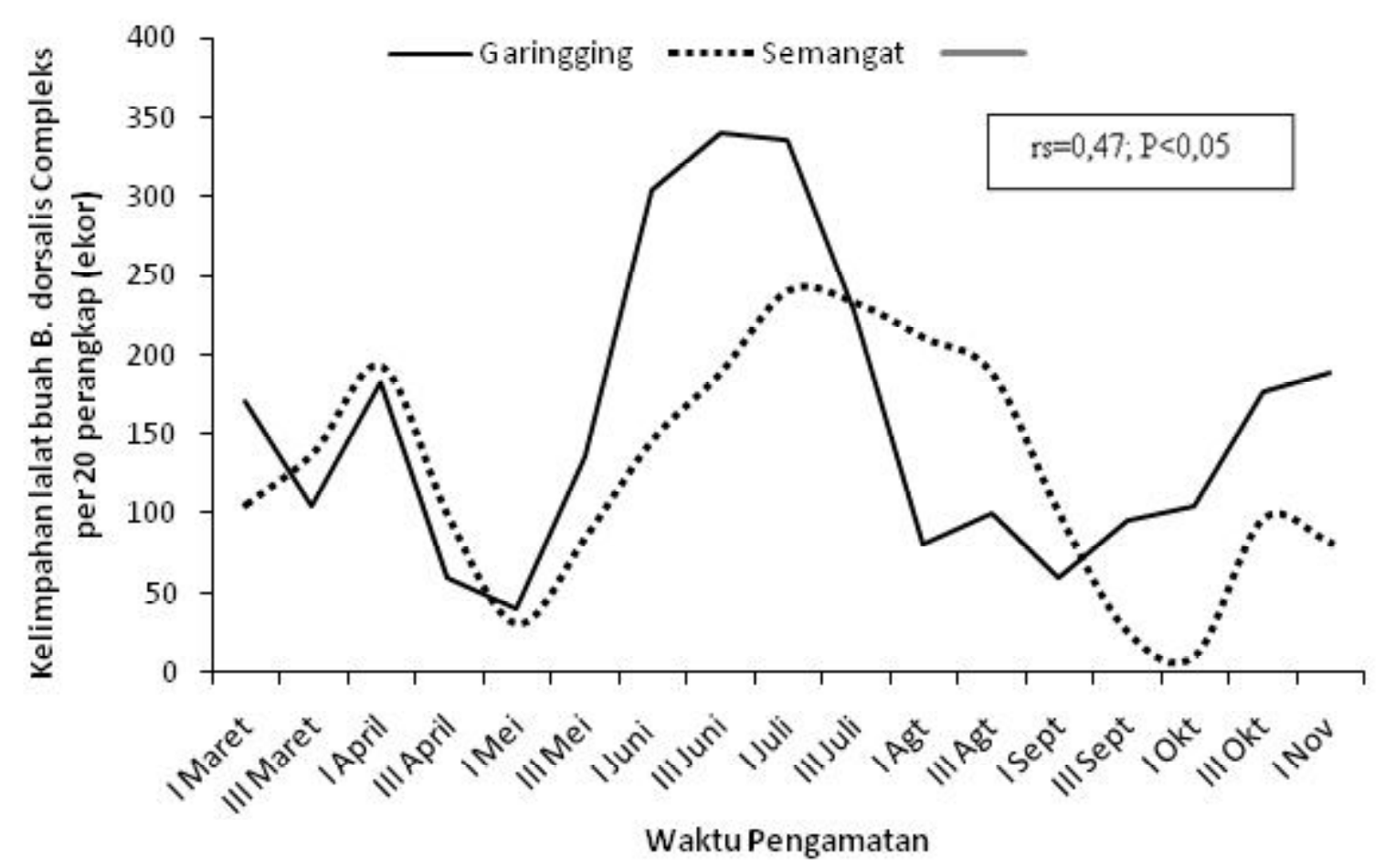

Gambar 1. Pola dinamika populasi lalat buah Bactrocera dorsalis complex pada pertanaman jeruk di dua Desa di Kabupaten Karo dari bulan Maret hingga November 2011.

Tabel 3. Faktor iklim (curah hujan, hari hujan dan suhu) serta kelimpahan rata-rata per bulan lalat buah Bactrocera dorsalis complex yang tertangkap dari bulan Maret hingga November 2011 di Kabupaten Karo Provinsi Sumatera Utara

\begin{tabular}{lcccc}
\hline Waktu & Curah Hujan $(\mathrm{ml})$ & Hari Hujan $(\mathrm{d})$ & Suhu $\left({ }^{\circ} \mathrm{C}\right)$ & Jumlah Lalat Buah (Ekor) \\
\hline Maret & 4,7 & 17 & 19 & 129 \\
April & 6,8 & 15 & 19,1 & 133 \\
Mei & 2,6 & 13 & 19,5 & 73 \\
Juni & 2,1 & 9 & 19,1 & 245 \\
Juli & 0,4 & 2 & 18,9 & 259 \\
Agustus & 11,1 & 19 & 18,6 & 145 \\
September & 3,8 & 13 & 18,7 & 70 \\
Oktober & 5,8 & 18 & 18,7 & 96 \\
November & 7,6 & 17 & 21,6 & 134 \\
\hline
\end{tabular}

buah Bactrocera spp. telah juga dilaporkan oleh Chen et al. (2006) dan Hasyim et al. (2008).

\section{SIMPULAN}

Lalat buah Bactrocera dorsalis complex pada pertanaman jeruk di dataran tinggi Kabupaten KaroProvinsi Sumatera Utara lebih aktif pada pagi hari pukul 10.00-12.00 WIB. Puncak kelimpahan populasinya terjadi pada bulan Juni hingga Juli bersamaan dengan terjadinya masa pematangan buah jeruk dan relatif sedikitnya jumlah hari hujan dan curah hujan. Dinamika populasi lalat buah Bactrocera dorsalis complex pada dua lokasi pertanaman jeruk yang diselidiki menunjukkan pola yang relatif sama. Jumlah hari hujan dan curah hujan setempat secara bersama-sama berkorelasi negatif terhadap kelimpahan dan dinamika populasi lalat buah. 


\section{SANWACANA}

Tim Peneliti mengucapkan terimakasih kepada Ditjen Dikti-DP2M Dikti Depdiknas yang telah mendanai pelaksanaan penelitian ini dengan Surat Perjanjian Hibah Penugasan Penelitian Fundamental No.199/SP2H/PL/ Dit.Litabmas/IV/2011 tanggal 14 April 2011. Demikian juga kepada Parningotan Sijabat pada BMG-Stasiun Klimatologi Kuta Gadung Kabupaten Karo yang telah bersedia menyediakan data suhu, jumlah hari hujan dan curah hujan.

\section{DAFTAR PUSTAKA}

Asokan R, Kumar NKK \& Verghese A. 2007. Molecular identification of fruit flies Bactrocera spp. (Diptera: Tephritidae) using mitochondrial cytochrome oxidase I. Current Science 93 (12): 1668-1669.

Drew RAI \& Hancock DL. 1994. The Bactrocera dorsalis complex of fruit flies (Diptera: Tephritidae: Dacinae) in Asia. Bulletin of Entomological Research Suppl. (2): 1-68.

Chen CC, Dong YJ, Lie CT, Lin KY \& Cheng LL. 2006. Movement of the oriental fruit fly, Bactrocera dorsalis (Hendel) (Diptera: Tephritidae) in a Guava orchard with special reference to its population changes. Formosan Entomol. 26: 143159.

David BV \& Ananthakrishnan TN. 2006. General and Applied Entomology. Tata McGraw-Hill Publishing Company Limited, New Delhi.

Gupta D \& Bahatia R. 2000. Population fluctuations of fruit flies, Bactrocera spp. in sub mountainous mango and guava orchards. J. Appl. Hort. 2(1): 47-49.

Hasyim A, Muryati \& de Kogel WJ. 2008. Population fluctuation of adult males of the fruit fly Bactrocera tau Walker (Diptera: Tephritidae) in passion fruit orchards in relation to abiotic factors and sanitation. Indonesian Journal of Agricultural Sciences 9(1): 29-33.

Honek A \& Kocourek F. 1990. Temperature and development time in insects: A general relationship between thermal constants. Zool. Jb. Syst. 117: 401-439.
Hutasoit K. 2004. Petani dan Kebun Jeruk. http:// www.mediaindo.12.co.id./berita.asp (Diakses 4 Maret 2010).

Kalie MB. 1992. Mengatasi Buah Rontok, Busuk dan Berulat. Penerbar Swadaya, Jakarta.

Kardinan A. 2003. Tanaman Pengendali Lalat Buah. Agromedia Pustaka, Jakarta.

Kusnaedi.1995. Pengendalian Hama Tanpa Pestisida. Penebar Swadaya, Jakarta.

Liu YC \& Yeh CC. 1982. Population fluctuation of oriental fruit fly Dacus dorsalis Hendel in sterile fly release and control area. Chinese J. Entomol. 2: 57-70.

Manik L \& Bangun A. 2004. Sumut Terima Alokasi Terbesar, Deptan Siapkan Rp.1 Miliar.Kendalikan Hama Lalat Buah. http/www.sebayak.org./ berita.php.id (Diakses 4 Maret 2010).

Manurung B, Witsack W, Mehner S, Grüntzig M \& Fuchs E. 2004. The epidemiology of Wheat dwarf virus in relation to occurrence of the leafhopper Psammotettix alienus in Middle-Germany. Virus Research 100: 109-113.

Manurung B, Witsack W, Mehner S, Grüntzig M \& Fuchs E. 2005. Studies on biology and population dynamics of the leafhopper Psammotettix alienus Dahlb. (Homoptera:Auchenorrhyncha) as vector of wheat dwarf virus (WDV) in Saxony-Anhalt, Germany. Journal of Plant Diseases and Protection 112 (5): 497-50

Palti J \& Ausher R. 1983. Advisory Work in Crop Pest and Disease Management. Springer-Verlag, New York.

Putra NS. 1997. Hama Lalat Buah dan Pengendalianya. Penerbit Kanisius, Yogjakarta.

Shehata NF, Younes MWF \& Mahmoud YA. 2008. Biological studies on the peach fruit fly Bactrocera zonata (Saunders) in Egypt. Journal of Applied Sciences Research 4(9): 1103-1106.

Siwi SS, Hidayat P \& Suputa. 2006. Taksonomi dan Bioekologi Lalat Buah Penting di Indonesia (Diptera: Tephritidae). BB Biogen \& Dept. Agriculture, Fisheries \& Forestry Australia, Bogor. 
Tobing MC, Marheni, Mariati \& Sipayung R. 2007. Pengaruh metil eugenol dalam pengendalian lalat buah (Bactrocera dorsalis) pada pertanaman jeruk. Jurnal Natur Indonesia 9 (2): 127-130.
White IM \& Elson-Harris MM. 1994. Fruit Flies of Economic Significance, Their Identification and Bionomics. CAB International, WallingfordUK.

Zar JH. 2010. Biostatistical Analysis. $5^{\text {th }}$ Edition. Prentice-Hall International, Inc., New Jersey. 


\title{
POLA AKTIVITAS HARIAN DAN DINAMIKA POPULASI LALAT BUAH BACTROCERA DORSALIS COMPLEX PADA PERTANAMAN JERUK DI DATARAN TINGGI KABUPATEN KARO PROVINSI SUMATERA UTARA
}

\author{
Binari Manurung, Puji Prastowo \& Emmi Ebrina Tarigan \\ Jurusan Biologi-Universitas Negeri Medan, Jln. Williem Iskandar Psr. V Medan Estate. \\ E-mail: binari44@hotmail.com
}

\begin{abstract}
Daily activity pattern and population dynamic of fruit fly Bactrocera dorsalis complex on citrus plantation at highland Karo district North Sumatera Province. The fruit fly Bactrocera dorsalis complex is important pest on citrus plantation at highland Karo district North Sumatera Province. The studies with the aim to find out its daily activity pattern and population dynamic on citrus plantation have been done. Fruit flies were collected by water bottle trap with methyl eugenol attractant. Sampling for daily activity pattern was done per two hours for two months (April to May 2011) from 06.00 a.m until 18.00 p.m. Meanwhile, population dynamic study was conducted on two citrus plantations per four days for nine months (March to November 2011) in the first and third week of each month. The research result showed that B.dorsalis complex was more active during morning at 10.00 to $12.00 \mathrm{a}$.m. The peak abundance of fruit fly occurred at the end of June until beginning of July. The peak population coincided with the ripening period of fruits, low number of rainy $(\mathrm{d})$ and rainfall $(\mathrm{mm})$ in June and July periods. There was a significant correlation between number of rainy day and rainfall with fruit flies caught per month $(\mathrm{R}=0.79 ; \mathrm{Y}=$ $\left.289.34+14.23 \mathrm{X}_{1}-15.93 \mathrm{X}_{2} ; \mathrm{R}^{2}=0.62 ; \mathrm{P}<0.05\right)$. The pattern of fruit fly fluctuation in two citrus plantations was similar $\left(\mathrm{r}_{\mathrm{s}}=0.47\right.$; $\mathrm{P}<0.05)$.
\end{abstract}

Keywords: fruit fly Bactrocera dorsalis complex, daily activity pattern, population dynamic

\begin{abstract}
ABSTRAK
Pola aktivitas harian dan dinamika populasi lalat buah Bactrocera dorsalis complex pada pertanaman jeruk di dataran tinggi Kabupaten Karo Provinsi Sumatera Utara. Lalat buah Bactrocera dorsalis complex merupakan hama penting tanaman jeruk di dataran tinggi Kabupaten Karo-Provinsi Sumatera Utara. Suatu penelitian yang bertujuan untuk mengkaji pola waktu aktivitas harian dan dinamika populasinya telah dilakukan. Sampel lalat buah ditangkap dengan menggunakan perangkap Steiner (botol bekas air mineral) yang diberi zat pemikat metil eugenol. Sampling untuk kajian pola aktivitas harian dilakukan per dua jam selama dua bulan ( April -Mei 2011) dari pukul 06.00-18.00 WIB, sedangkan untuk dinamika populasi dilakukan pada dua pertanaman jeruk per empat hari selama sembilan bulan (Maret 2011-November 2011) yakni pada minggu I dan III setiap bulannya. Hasil penelitian menunjukkan B. dorsalis complex lebih aktif pada pagi hari pukul 10.00-12.00 WIB. Kelimpahan puncak terjadi pada akhir Juni hingga awal Juli. Puncak populasi terjadi bersamaan dengan masa pematangan buah jeruk, rendahnya jumlah hari hujan dan curah hujan pada bulan Juni dan Juli. Terdapat hubungan yang signifikan antara jumlah hari hujan dan curah hujan dengan jumlah lalat buah yang tertangkap setiap bulan $\left(\mathrm{R}=0,79 ; \mathrm{Y}=289,34+14,23 \mathrm{X}_{1}\right.$ $\left.15,93 \mathrm{X}_{2} ; \mathrm{R}^{2}=0,62 ; \mathrm{P}<0.05\right)$. Dinamika populasi lalat buah pada dua lokasi pertanaman jeruk yang diselidiki menunjukkan pola yang relatif sama $\left(\mathrm{r}_{\mathrm{s}}=0.47 ; \mathrm{P}<0.05\right)$.
\end{abstract}

Kata kunci: lalat buah Bactrocera dorsalis complex, pola aktivitas harian, dinamika populasi

\section{PENDAHULUAN}

Kabupaten Karo yang berada di daerah pegunungan pada ketinggian $1400 \mathrm{~m}$ di atas permukaan laut merupakan salah satu pusat produksi buah-buahan, khususnya jeruk manis (Citrus sp.). Namun produksi jeruk dari Kabupaten tersebut sejak tahun 2003 telah mengalami penurunan yang sangat drastis. Hal itu terjadi karena buah tanaman jeruk yang berada di daerah ini diserang oleh lalat buah Bactrocera sp. (Diptera: Tephritidae). Menurut Hasyim et al. (2008) sebagai salah satu serangga hama penting tanaman hortikultura di daerah tropis dan subtropis, lalat buah meletakkan telurnya di bawah kulit buah, kemudian menetas menjadi larva dan selanjutnya mengkonsumsi daging buah. Buah yang terserang lalat buah akan menjadi lebih cepat busuk dan jatuh dari pohonnya sebelum waktunya (Hutasoit, 2004). 
Hama lalat buah diperkirakan telah merusak sekitar 17.000 hektar tanaman jeruk yang berada di daerah Kabupaten Karo dan menyebabkan produksi per hektarnya mengalami penurunan yang drastis menjadi 20 ton dari sebelumnya 60 ton. Bahkan kualitas buah jeruk yang dihasilkannya juga amat buruk sehingga harga jualnya di tingkat petani turun hingga 50\% (Manik \& Bangun, 2004).

Surat Kabar Harian Medan Bisnis pada 31 Mei 2004 memberitakan bahwa lalat buah yang menyerang tanaman jeruk yang berada di dataran tinggi provinsi Sumatra secara signifikan mampu mengurangi produksi sampai $70 \%$. Sehubungan dengan masalah tersebut pada bulan Mei 2004 gerakan pengendalian massal lalat buah telah dicanangkan, ditandai dengan pemukulan gong oleh Menteri Pertanian Republik Indonesia.

Salah satu langkah penting yang harus dilakukan dalam rangka monitoring dan pengendalian lalat buah yang menyerang tanaman jeruk adalah memahami bioekologi dari lalat buah tersebut. Sejumlah hasil penelitian tentang bioekologi lalat buah Bactrocera spp. telah dilaporkan oleh beberapa peneliti. Misalnya, Shehata et al. (2008) tentang biologi perkembangannya; Hasyim et al. (2008) tentang fluktuasi populasinya, Chen et al. (2006) perihal migrasi dan perubahan populasinya; dan Asokan et al. (2007) tentang biologi molekularnya.

Informasi mengenai bioekologi lalat buah Bactrocera spp. yang menyerang tanaman jeruk di Kabupaten Karo Sumatera Utara masih sangat terbatas. Penelitian yang telah dilakukan diantaranya masih berkaitan dengan keanekaragaman spesies dan pengaruh metil eugenol dalam pengendalian populasinya. Spesies lalat buah yang menyerang tanaman jeruk adalah Bactrocera dorsalis dan metil eugenol dengan menggunakan perangkap Steiner dapat dipergunakan untuk mengendalikan populasinya (Tobing et al., 2007).

Penelitian bertujuan untuk mengetahui pola aktivitas harian, kelimpahan dan dinamika populasi lalat buah dalam hubungannya dengan tingkat kematangan buah jeruk, perbedaan kelimpahan dan pola dinamika populasi lalat buah pada dua pertanaman jeruk serta hubungan antara faktor lingkungan (iklim) dengan kelimpahan/dinamika populasi lalat buah. Pemahaman tentang hal ini mempunyai kontribusi penting dalam monitoring ataupun pengendalian populasi lalat buah di lapangan. Kepentingan data semacam itu untuk monitoring dan pengendalian populasi serangga di lapangan saat menjadi hama pertanian telah dilaporkan oleh Manurung et al. (2004 \& 2005).

\section{METODE PENELITIAN}

Pola Aktivitas Harian. Penelitian dilakukan pada pertanaman jeruk manis di Desa Semangat Kecamatan Merdeka yang terletak pada ketinggian sekitar $1360 \mathrm{~m}$ di atas permukaan laut. Luas pertanaman jeruk tersebut $3000 \mathrm{~m}^{2}$ dan terdapat 500 pohon jeruk. Tanaman jeruk telah berumur sekitar 7 (tujuh) tahun. Pemerangkapan lalat buah dilakukan dengan menggunakan tipe perangkap Steiner yang telah dimodifikasi, yakni berupa botol bekas air mineral berukuran $1500 \mathrm{ml}$ yang salah satu bagian ujungnya diubah sedemikian rupa sehingga dapat berperan sebagai pintu masuk bagi lalat buah (Putra, 1997; Gupta \& Bhatia, 2000; Kardinan, 2003 \& Hasyim et al., 2008). Pada kawat yang terdapat pada bagian dalam botol digantungkan kapas sebesar ibu jari dan ditetesi zat pemikat metil eugenol sebanyak empat tetes. Perangkap digantung pada pohon jeruk pada ketinggian 1,5 meter dari permukaan tanah. Jumlah perangkap yang digunakan sebanyak 20 buah. Pemasangan perangkap berlangsung dari pukul 06.00 hingga pukul 18.00 WIB. Pemerangkapan dilakukan satu kali dalam seminggu dari bulan April hingga Mei 2011, sehingga secara total dilakukan delapan kali ulangan. Pengidentifikasian lalat buah di laboratorium dilakukan dengan bantuan mikroskop stereo binokuler merek Olympus SZ 51 dan mengacu kepada pustaka Drew \& Hancock (1994), White \& Elson-Harris (1994) dan Siwi et al. (2006). Variabel penelitian adalah jumlah lalat buah Bactrocera dorsalis complex yang tertangkap dalam perangkap per dua jam dan dinyatakan dalam proporsi (\%). Untuk mengetahui signifikansi perbedaan waktu aktivitas lalat buah pada pagi, siang dan sore hari digunakan uji Kruskal-Wallis (Zar, 2010).

Kelimpahan dan Dinamika Populasi. Penelitian dilakukan pada dua pertanaman jeruk, yakni di Desa Semangat Kecamatan Merdeka dan Desa Garingging Kecamatan Merek. Luas pertanaman jeruk di Desa Garingging juga sekitar $3000 \mathrm{~m}^{2}$ dan ditanami 500 pohon jeruk. Desa Garingging terletak sekitar $1352 \mathrm{~m}$ di atas permukaan laut. Jarak antar kedua pertanaman jeruk yang menjadi lokasi penelitian lebih kurang $25 \mathrm{~km}$. Pendekatan penelitiannya didasarkan kepada modifikasi metode yang dikemukakan oleh Gupta \& Bhatia (2000), Chen et al. (2006) dan Hasyim et al. (2008). Dalam hal ini, masing-masing pada kedua pertanaman jeruk dipasang 20 perangkap berupa botol air mineral bekas. Pada kapas yang tergantung dalam perangkap ditetesi 
empat tetes metil eugenol yang berperan sebagai zat pemikat bagi lalat buah. Selanjutnya perangkap ditempatkan pada ketinggian 1,5 m dari permukaan tanah. Setelah empat hari, lalat buah yang terperangkap diambil dan dibawa ke laboratorium untuk selanjutnya disortir, diidentifikasi dan dihitung jumlahnya. Pemerangkapan lalat buah dilakukan pada setiap minggu pertama dan minggu ketiga dari bulan Maret hingga November 2011, sehingga jumlah total sampling 17 kali. Selama masa pemerangkapan lalat buah, tingkat kematangan buah jeruk di lapangan juga diamati dan dicatat. Identifikasi dan penghitungan lalat buah dilakukan sebagaimana pada metode pola aktivitas harian di atas. Variabel penelitian adalah jumlah Bactrocera dorsalis complex yang terperangkap per empat hari selama 17 minggu penelitian. Dengan data tersebut dinamika populasi Bactrocera dorsalis complex selama 17 minggu pengamatan dapat diketahui, demikian juga dengan waktu terjadinya puncak populasinya. Signifikansi perbedaan kelimpahan lalat buah pada dua pertanaman jeruk diuji dengan menggunakan uji t, sedangkan perbedaan dinamika populasinya dengan analisis korelasi tata jenjang (Zar, 2010).

Data iklim berupa suhu, jumlah hari hujan dan curah hujan dari Badan Meteorologi dan Geofisika (BMG) setempat (stasiun Kuta Gadung) dipergunakan untuk mengetahui pengaruhnya terhadap kelimpahan dan dinamika populasi lalat buah. Dalam hal ini pengujiannya dilakukan dengan menggunakan uji regresi ganda bertahap (Zar, 2010).

\section{HASIL DAN PEMBAHASAN}

Pola Aktivitas Harian. Lalat buah Bactrocera dorsalis complex memiliki pola aktivitas harian yang lebih aktif pada pagi hari jam pukul 10.00-12.00 WIB hingga siang hari 12.00-14.00 WIB (Tabel 1). Hal ini ditunjukkan oleh banyaknya lalat buah yang tertangkap pada perangkap Steiner yang diberi metil eugenol. Pada pagi hari (10.00-12.00 WIB), proporsi lalat buah yang tertangkap sebesar 29\% (167 individu) dan siang hari 28\% (159 individu). Pada pagi hari (06.00-08.00 WIB) dan sore hari (16.00-18.00 WIB) proporsi lalat buah yang aktif relatif sedikit, yakni hanya 2\% (12 individu) dan 6\% (35 individu). Berdasarkan data jumlah lalat buah yang tertangkap dapat dikemukakan puncak waktu aktif lalat buah pada pertanaman jeruk terjadi pada pagi hari pukul 10.00-12.00 WIB. Hasil uji Kruskal-Wallis menunjukkan perbedaan waktu aktif lalat buah tersebut sangat signifikan $(\mathrm{H}=26,82 ; \mathrm{P}<0,01)$.

Lebih banyaknya lalat buah yang aktif pada pagi hari hingga siang hari (10.00-14.00 WIB) dan sebaliknya relatif sedikitnya lalat buah yang aktif pada pagi hari pukul 06.00-08.00 WIB dan sore hari pukul 16.00-18.00 WIB mungkin erat kaitannya dengan sifat lalat buah yang ektoterm dan suhu lingkungan yang ada di dataran tinggi tanah Karo. Dalam hal ini agar lalat buah tersebut dapat memulai aktivitasnya (seperti menggerakkan mata, sungut, kaki, sayap hingga akhirnya terbang mencari makanan dan pasangan hidup) harus terlebih dahulu suhu ambang tubuhnya (threshold temperature) terlampaui (David \& Ananthakrishnan, 2006; Honek \& Kocourek, 1990). Menurut Liu \& Yeh (1982) dan Chen et al. (2006) suhu ambang tubuh lalat buah sekitar $18^{\circ} \mathrm{C}$. Sementara itu, menurut Badan Meteorologi dan Geofisika (BMG) setempat suhu rata-rata pada pagi hari di dataran tinggi Kabupaten Karo pada bulan April dan Mei (waktu penelitian dilaksanakan) adalah $16,9-17,3^{\circ} \mathrm{C}$, siang hari $22,9-23,5^{\circ} \mathrm{C}$ dan sore hari $19,1-19,4^{\circ} \mathrm{C}$. Jadi kondisi suhu lingkungan yang masih rendah pada pagi hari pukul 06.0008.00 WIB mungkin yang menyebabkan lebih sedikitnya proporsi lalat buah yang tertangkap pada pagi, demikian juga pada sore hari pukul 16.00-18.00 WIB jika dibandingkan dengan pada pagi hari pukul 10.00-12.00 WIB hingga siang hari pukul 12.00-14.00 WIB.

Hasil yang diperoleh pada penelitian ini menkonfirmasi hasil penelitian yang telah dilaporkan oleh Tobing et al. (2007) yang menyatakan bahwa lalat buah

Tabel 1. Proporsi lalat buah Bactrocera dorsalis complex yang tertangkap pada perangkap Steiner dari pukul 06.00-18.00 WIB pada pertanaman jeruk di Kabupaten Karo Provinsi Sumatera Utara

\begin{tabular}{cccc}
\hline No & Waktu & Jumlah tangkapan (individu) & Proporsi (\%) \\
\hline 1 & $06.00-08.00$ & 12 & 2 \\
2 & $08.00-10.00$ & 131 & 23 \\
3 & $10.00-12.00$ & 167 & 29 \\
4 & $12.00-14.00$ & 159 & 28 \\
5 & $14.00-16.00$ & 67 & 12 \\
6 & $16.00-18.00$ & 35 & 6 \\
\hline
\end{tabular}


lebih aktif pada pagi hari, akan tetapi penelitian tersebut belum mengungkapkan waktu aktifnya pada pagi hari tersebut. Sementara hasil penelitian ini menunjukkan bahwa waktu aktif lalat buah tersebut yaitu pada pukul 10.00-12.00 WIB. Selanjutnya, jika dibandingkan dengan hasil yang telah dilaporkan oleh Chen et al. (2006) relatif berbeda. Dalam hal ini Chen et al (2006) menyatakan populasi lalat buah Bactorcera dorsalis pada kebun Jambu mencapai puncaknya pada sore hari. Perbedaan hasil itu dapat dijelaskan karena Chen et al. (2006) melakukan pemerangkapan hanya pada pagi hari pukul 09.00 dan sore hari pukul 15.00 WIB. Itu berarti data lalat buah yang tertangkap pada siang hari tidak tersedia.Hal itulah mungkin yang menyebabkan mengapa hasil yang diperoleh pada penelitian ini berbeda dengan hasil yang telah dilaporkan oleh Chen et al. (2006) tersebut.

Kelimpahan dan Dinamika Populasi. Selama penelitian diperoleh lalat buah Bactrocera dorsalis complex sebanyak 2519 individu pada pertanaman jeruk di Desa Garingging dan 2160 individu di Desa Semangat
(Tabel 2). Jadi kelimpahan lalat buah pada pertanaman jeruk yang terdapat di Desa Garingging lebih banyak dibandingkan dengan yang terdapat di desa Semangat. Perbedaan kelimpahan lalat buah tersebut berdasarkan hasil uji t tidak signifikan ( $\mathrm{t}$ hitung $=1,10 ; \mathrm{P}>0,05$ ). Kelimpahan tertinggi lalat buah pada desa Garingging 340 individu terjadi pada Minggu III bulan Juni sedangkan yang terendahnya 40 individu terjadi pada Minggu I bulan Mei. Sementara itu, di Desa Semangat, kelimpahan tertingginya hanya mencapai 240 individu terjadi pada Minggu I bulan Juli dan terendahnya 30 individu terjadi juga pada Minggu I bulan Mei. Oleh karena itu, puncak kelimpahan lalat buah pada kedua pertanaman jeruk tersebut terjadi pada akhir bulan Juni hingga awal bulan Juli. Lebih lanjut dapat dikemukakan populasi lalat buah berfluktuasi seiring dengan berjalannya waktu. Dalam hal ini pada periode bulan Maret - April 2011 jumlahnya relatif lebih banyak dibandingkan pada bulan Mei yang jumlahnya menurun. Pada bulan Juni dan Juli bahkan hingga bulan Agustus jumlahnya meningkat lagi. Selanjutnya pada bulan September jumlahnya menurun lagi dan kemudian

Tabel 2. Kelimpahan lalat buah Bactrocera dorsalis Compleks per 20 perangkap dari Maret hingga November 2011 di dua pertanaman jeruk di Kabupaten Karo-Propinsi Sumatera Utara

\begin{tabular}{cllc}
\hline No & Waktu & $\begin{array}{c}\text { Kelimpahan lalat buah (ekor) } \\
\text { di Desa Garingging }\end{array}$ & $\begin{array}{c}\text { Kelimpahan lalat buah (ekor) } \\
\text { di Desa Semangat }\end{array}$ \\
\hline 1 & I. Maret & 170 & 105 \\
2 & III. Maret & 105 & 138 \\
3 & I. April & 182 & 192 \\
4 & III. April & 60 & 96 \\
5 & I. Mei & 40 & 30 \\
6 & III. Mei & 136 & 84 \\
7 & I. Juni & 304 & 146 \\
8 & III. Juni & 340 & 188 \\
9 & I. Juli & 336 & 240 \\
10 & III. Juli & 228 & 232 \\
11 & I. Agustus & 80 & 210 \\
12 & III. Agustus & 100 & 188 \\
13 & I. September & 60 & 99 \\
14 & III. September & 96 & 25 \\
15 & I. Oktober & 105 & 10 \\
16 & III. Oktober & 177 & 96 \\
17 & I. November & 188 & 81 \\
\hline Jumlah total & 2519 & 2160 \\
Rataan & Simpangan baku & 59,23 & 72,05 \\
Simp & 95,36 & \\
\hline
\end{tabular}


meningkat lagi hingga minggu I bulan November 2011. Adanya perubahan kelimpahan populasi ataupun dinamika populasi lalat buah Bactrocera spp. pada berbagai tanaman inang telah dilaporkan oleh sejumlah peneliti, diantaranya Gupta \& Bahatia (2000); Chen et al. (2006) dan Hasyim et al. (2008). Perubahan kelimpahan tersebut erat kaitannya dengan keadaan faktor lingkungan abiotik dan abiotik dimana lalat buah tersebut hidup ataupun berada (Chen et al., 2006 dan Hasyim et al., 2008).

Berdasarkan pengamatan di lapangan, tampaknya ada hubungan antara jumlah lalat buah yang tertangkap dengan fase pertumbuhan dan perkembangan tanaman jeruk atau dengan kata lain tingkat kematangan buah jeruk. Kelimpahan tertinggi diperoleh bersamaan dengan ukuran buah jeruk sebesar bola kasti dan warnanya hijau kekuningan, sedangkan kelimpahan terendah terjadi saat buah jeruk berukuran kecil sebesar kelereng dan masih berwarna kehijaun.

Ketika sampling pertama dilakukan pada Minggu I bulan Maret 2011, buah jeruk baru saja dipanen, tepatnya pada bulan Februari. Pada saat itu yang tersisa hanyalah buah jeruk yang berukuran kecil (sebesar kelereng) dan berwarna hijau. Kondisi jeruk yang sedemikian mungkin yang menjadi penyebab mengapa jumlah lalat buah yang tertangkap pada bulan Mei relatif sedikit.

Selanjutnya, pada bulan Juni dan Juli, buah jeruk di lapangan telah ada dalam ukuran yang relatif besar (sebesar bola kasti) dan lebih matang yang ditandai dengan perubahan warna dari hijau menjadi kuning. Pada kondisi jeruk yang sedemikian jumlah lalat buah yang tertangkap relatif banyak. Terjadinya hal itu mungkin erat kaitannya dengan bau ataupun aroma ester yang dihasilkan buah jeruk saat mengalami perubahan warna dari hijau ke kuning, demikian juga dengan warna kuning dari buah jeruk. Hal ini sesuai dengan apa yang dikemukakan oleh Palti \& Ausher (1983), Kalie (1992) dan juga Kusnaedi (1995), bahwa bau atau aroma ester dan visualisasi kuning dari buah jeruk sangat disukai oleh lalat buah. Kedua faktor tersebut mungkin yang menyebabkan jumlah lalat buah yang tertangkap pada bulan Juni hingga Juli 2011 pada pertanaman jeruk menjadi meningkat. Adanya hubungan antara tingkat kematangan buah dengan dinamika/fluktuasi populasi lalat buah di lapangan lebih lanjut juga telah dilaporkan oleh Gupta \& Bahatia (2000), Chen et al. (2006) dan Hasyim et al. (2008).

Pada awal Agustus 2011, buah jeruk telah dipanen pada Desa Garingging sedangkan di Desa Merdeka pada akhir Agustus 2011. Keadaan seperti itu menyebabkan buah jeruk yang tersisa di lapangan hanya buah yang berukuran kecil dengan warna hijau. Kondisi tersebut menyebabkan visualisasi kuning sebagai warna penarik bagi lalat buah, demikian juga halnya dengan tidak adanya aroma ester yang keluar dari buah jeruk menyebabkan jumlah lalat buah yang tertangkap mulai pertengahan bulan Agustus 2011 di Desa Garingging dan bulan September 2011 di Desa Semangat menjadi berkurang.

Selanjutnya, dengan berubahnya ukuran jeruk, dalam hal ini menjadi lebih besar dan mulai adanya jeruk yang berwarna hijau kekuningan pada bulan Oktober 2011, jumlah populasi lalat buah kembali meningkat. Peningkatan itu tampak terjadi mulai bulan Oktober hingga awal bulan November 2011.

Sementara itu, berdasarkan hasil uji korelasi tata jenjang dapat dikemukakan lebih lanjut bahwa kecenderungan pola fluktuasi yakni naik turunnya populasi lalat buah pada kedua pertanaman jeruk yang diselidiki (antara Desa Garingging dan Semangat) relatif sama. Hal itu ditunjukkan oleh adanya korelasi yang signifikan antara jumlah lalat buah yang tertangkap per satuan waktu pada Desa Garingging dengan jumlah yang tertangkap di Desa Semangat $\left(r_{s}=0,47 ; P<0,05\right)$ (Gambar 1). Terjadinya kesamaan pola dinamika populasi tersebut mungkin erat kaitannya dengan kesamaan waktu berbunga, pertumbuhan dan perkembangan buah jeruk, terutama masa perubahan warna buah dari hijau ke kuning bahkan waktu panen jeruk pada kedua areal pertanaman yang diselidiki relatif sama, termasuk kondisi faktor abiotik lingkungannya terutama suhu, jumlah hari hujan dan curah hujannya.

Di samping faktor tingkat kematangan buah, faktor lain yang juga turut berperan dalam mempengaruhi kelimpahan dan dinamika populasi lalat buah pada kedua lokasi penelitian adalah faktor jumlah curah hujan $\left(X_{1}\right)$ dan hari hujan $\left(X_{2}\right)$ (Tabel 3). Dalam hal ini hasil analisis regresi ganda bertahap menunjukkan hanya faktor jumlah curah hujan dan hari hujan yang secara bersama-sama berpengaruh atau berkorelasi signifikan dengan kelimpahan dan dinamika populasi lalat buah $\left(\mathrm{R}=0,79 ; \mathrm{Y}=289,34+14,23 \mathrm{X}_{1}-15,93 \mathrm{X}_{2} ; \mathrm{R}^{2}=0,62\right.$; $\mathrm{P}<0,05)$, sedangkan suhu lingkungan setempat tidak berpengaruh $\left(r=0,05 ; Y=-3,63 X_{3}+216,6 ; R^{2}=0,002\right.$; $\mathrm{P}>0,05)$. Sehubungan dengan itu, jumlah curah hujan dan hari hujan yang relatif rendah pada bulan Juni dan Juli juga perlu mendapat perhatian khusus dari petani jeruk dalam rangka pengendalian populasi lalat buah di lapangan. Adanya pengaruh faktor abiotik lingkungan seperti jumlah curah hujan dan hari hujan dalam mempengaruhi kelimpahan dan dinamika populasi lalat 


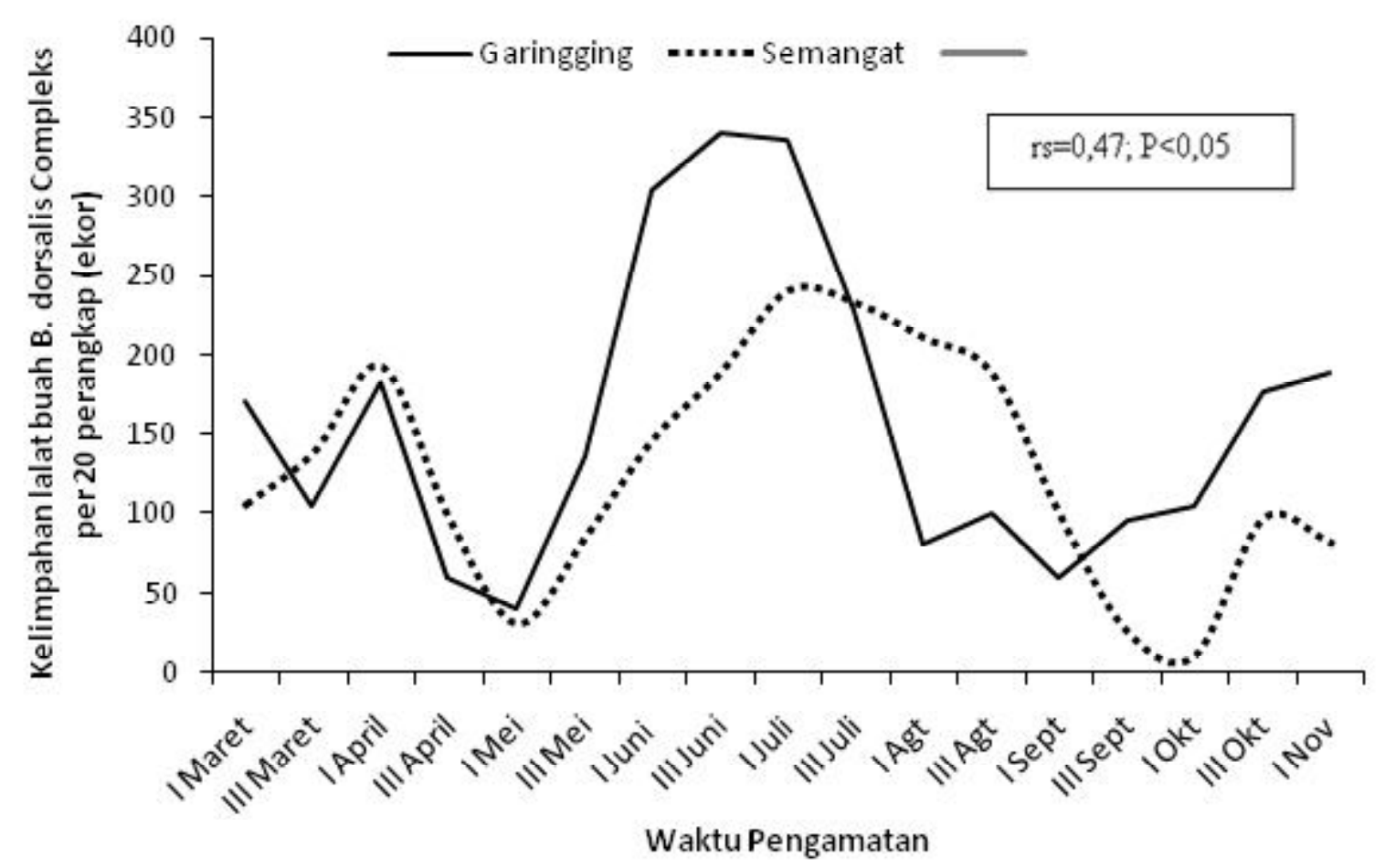

Gambar 1. Pola dinamika populasi lalat buah Bactrocera dorsalis complex pada pertanaman jeruk di dua Desa di Kabupaten Karo dari bulan Maret hingga November 2011.

Tabel 3. Faktor iklim (curah hujan, hari hujan dan suhu) serta kelimpahan rata-rata per bulan lalat buah Bactrocera dorsalis complex yang tertangkap dari bulan Maret hingga November 2011 di Kabupaten Karo Provinsi Sumatera Utara

\begin{tabular}{lcccc}
\hline Waktu & Curah Hujan $(\mathrm{ml})$ & Hari Hujan $(\mathrm{d})$ & Suhu $\left({ }^{\circ} \mathrm{C}\right)$ & Jumlah Lalat Buah (Ekor) \\
\hline Maret & 4,7 & 17 & 19 & 129 \\
April & 6,8 & 15 & 19,1 & 133 \\
Mei & 2,6 & 13 & 19,5 & 73 \\
Juni & 2,1 & 9 & 19,1 & 245 \\
Juli & 0,4 & 2 & 18,9 & 259 \\
Agustus & 11,1 & 19 & 18,6 & 145 \\
September & 3,8 & 13 & 18,7 & 70 \\
Oktober & 5,8 & 18 & 18,7 & 96 \\
November & 7,6 & 17 & 21,6 & 134 \\
\hline
\end{tabular}

buah Bactrocera spp. telah juga dilaporkan oleh Chen et al. (2006) dan Hasyim et al. (2008).

\section{SIMPULAN}

Lalat buah Bactrocera dorsalis complex pada pertanaman jeruk di dataran tinggi Kabupaten KaroProvinsi Sumatera Utara lebih aktif pada pagi hari pukul 10.00-12.00 WIB. Puncak kelimpahan populasinya terjadi pada bulan Juni hingga Juli bersamaan dengan terjadinya masa pematangan buah jeruk dan relatif sedikitnya jumlah hari hujan dan curah hujan. Dinamika populasi lalat buah Bactrocera dorsalis complex pada dua lokasi pertanaman jeruk yang diselidiki menunjukkan pola yang relatif sama. Jumlah hari hujan dan curah hujan setempat secara bersama-sama berkorelasi negatif terhadap kelimpahan dan dinamika populasi lalat buah. 


\section{SANWACANA}

Tim Peneliti mengucapkan terimakasih kepada Ditjen Dikti-DP2M Dikti Depdiknas yang telah mendanai pelaksanaan penelitian ini dengan Surat Perjanjian Hibah Penugasan Penelitian Fundamental No.199/SP2H/PL/ Dit.Litabmas/IV/2011 tanggal 14 April 2011. Demikian juga kepada Parningotan Sijabat pada BMG-Stasiun Klimatologi Kuta Gadung Kabupaten Karo yang telah bersedia menyediakan data suhu, jumlah hari hujan dan curah hujan.

\section{DAFTAR PUSTAKA}

Asokan R, Kumar NKK \& Verghese A. 2007. Molecular identification of fruit flies Bactrocera spp. (Diptera: Tephritidae) using mitochondrial cytochrome oxidase I. Current Science 93 (12): 1668-1669.

Drew RAI \& Hancock DL. 1994. The Bactrocera dorsalis complex of fruit flies (Diptera: Tephritidae: Dacinae) in Asia. Bulletin of Entomological Research Suppl. (2): 1-68.

Chen CC, Dong YJ, Lie CT, Lin KY \& Cheng LL. 2006. Movement of the oriental fruit fly, Bactrocera dorsalis (Hendel) (Diptera: Tephritidae) in a Guava orchard with special reference to its population changes. Formosan Entomol. 26: 143159.

David BV \& Ananthakrishnan TN. 2006. General and Applied Entomology. Tata McGraw-Hill Publishing Company Limited, New Delhi.

Gupta D \& Bahatia R. 2000. Population fluctuations of fruit flies, Bactrocera spp. in sub mountainous mango and guava orchards. J. Appl. Hort. 2(1): 47-49.

Hasyim A, Muryati \& de Kogel WJ. 2008. Population fluctuation of adult males of the fruit fly Bactrocera tau Walker (Diptera: Tephritidae) in passion fruit orchards in relation to abiotic factors and sanitation. Indonesian Journal of Agricultural Sciences 9(1): 29-33.

Honek A \& Kocourek F. 1990. Temperature and development time in insects: A general relationship between thermal constants. Zool. Jb. Syst. 117: 401-439.
Hutasoit K. 2004. Petani dan Kebun Jeruk. http:// www.mediaindo.12.co.id./berita.asp (Diakses 4 Maret 2010).

Kalie MB. 1992. Mengatasi Buah Rontok, Busuk dan Berulat. Penerbar Swadaya, Jakarta.

Kardinan A. 2003. Tanaman Pengendali Lalat Buah. Agromedia Pustaka, Jakarta.

Kusnaedi.1995. Pengendalian Hama Tanpa Pestisida. Penebar Swadaya, Jakarta.

Liu YC \& Yeh CC. 1982. Population fluctuation of oriental fruit fly Dacus dorsalis Hendel in sterile fly release and control area. Chinese J. Entomol. 2: 57-70.

Manik L \& Bangun A. 2004. Sumut Terima Alokasi Terbesar, Deptan Siapkan Rp.1 Miliar.Kendalikan Hama Lalat Buah. http/www.sebayak.org./ berita.php.id (Diakses 4 Maret 2010).

Manurung B, Witsack W, Mehner S, Grüntzig M \& Fuchs E. 2004. The epidemiology of Wheat dwarf virus in relation to occurrence of the leafhopper Psammotettix alienus in Middle-Germany. Virus Research 100: 109-113.

Manurung B, Witsack W, Mehner S, Grüntzig M \& Fuchs E. 2005. Studies on biology and population dynamics of the leafhopper Psammotettix alienus Dahlb. (Homoptera:Auchenorrhyncha) as vector of wheat dwarf virus (WDV) in Saxony-Anhalt, Germany. Journal of Plant Diseases and Protection 112 (5): 497-50

Palti J \& Ausher R. 1983. Advisory Work in Crop Pest and Disease Management. Springer-Verlag, New York.

Putra NS. 1997. Hama Lalat Buah dan Pengendalianya. Penerbit Kanisius, Yogjakarta.

Shehata NF, Younes MWF \& Mahmoud YA. 2008. Biological studies on the peach fruit fly Bactrocera zonata (Saunders) in Egypt. Journal of Applied Sciences Research 4(9): 1103-1106.

Siwi SS, Hidayat P \& Suputa. 2006. Taksonomi dan Bioekologi Lalat Buah Penting di Indonesia (Diptera: Tephritidae). BB Biogen \& Dept. Agriculture, Fisheries \& Forestry Australia, Bogor. 
Tobing MC, Marheni, Mariati \& Sipayung R. 2007. Pengaruh metil eugenol dalam pengendalian lalat buah (Bactrocera dorsalis) pada pertanaman jeruk. Jurnal Natur Indonesia 9 (2): 127-130.
White IM \& Elson-Harris MM. 1994. Fruit Flies of Economic Significance, Their Identification and Bionomics. CAB International, WallingfordUK.

Zar JH. 2010. Biostatistical Analysis. $5^{\text {th }}$ Edition. Prentice-Hall International, Inc., New Jersey. 


\title{
POLA AKTIVITAS HARIAN DAN DINAMIKA POPULASI LALAT BUAH BACTROCERA DORSALIS COMPLEX PADA PERTANAMAN JERUK DI DATARAN TINGGI KABUPATEN KARO PROVINSI SUMATERA UTARA
}

\author{
Binari Manurung, Puji Prastowo \& Emmi Ebrina Tarigan \\ Jurusan Biologi-Universitas Negeri Medan, Jln. Williem Iskandar Psr. V Medan Estate. \\ E-mail: binari44@hotmail.com
}

\begin{abstract}
Daily activity pattern and population dynamic of fruit fly Bactrocera dorsalis complex on citrus plantation at highland Karo district North Sumatera Province. The fruit fly Bactrocera dorsalis complex is important pest on citrus plantation at highland Karo district North Sumatera Province. The studies with the aim to find out its daily activity pattern and population dynamic on citrus plantation have been done. Fruit flies were collected by water bottle trap with methyl eugenol attractant. Sampling for daily activity pattern was done per two hours for two months (April to May 2011) from 06.00 a.m until 18.00 p.m. Meanwhile, population dynamic study was conducted on two citrus plantations per four days for nine months (March to November 2011) in the first and third week of each month. The research result showed that B.dorsalis complex was more active during morning at 10.00 to $12.00 \mathrm{a}$.m. The peak abundance of fruit fly occurred at the end of June until beginning of July. The peak population coincided with the ripening period of fruits, low number of rainy $(\mathrm{d})$ and rainfall $(\mathrm{mm})$ in June and July periods. There was a significant correlation between number of rainy day and rainfall with fruit flies caught per month $(\mathrm{R}=0.79 ; \mathrm{Y}=$ $\left.289.34+14.23 \mathrm{X}_{1}-15.93 \mathrm{X}_{2} ; \mathrm{R}^{2}=0.62 ; \mathrm{P}<0.05\right)$. The pattern of fruit fly fluctuation in two citrus plantations was similar $\left(\mathrm{r}_{\mathrm{s}}=0.47\right.$; $\mathrm{P}<0.05)$.
\end{abstract}

Keywords: fruit fly Bactrocera dorsalis complex, daily activity pattern, population dynamic

\begin{abstract}
ABSTRAK
Pola aktivitas harian dan dinamika populasi lalat buah Bactrocera dorsalis complex pada pertanaman jeruk di dataran tinggi Kabupaten Karo Provinsi Sumatera Utara. Lalat buah Bactrocera dorsalis complex merupakan hama penting tanaman jeruk di dataran tinggi Kabupaten Karo-Provinsi Sumatera Utara. Suatu penelitian yang bertujuan untuk mengkaji pola waktu aktivitas harian dan dinamika populasinya telah dilakukan. Sampel lalat buah ditangkap dengan menggunakan perangkap Steiner (botol bekas air mineral) yang diberi zat pemikat metil eugenol. Sampling untuk kajian pola aktivitas harian dilakukan per dua jam selama dua bulan ( April -Mei 2011) dari pukul 06.00-18.00 WIB, sedangkan untuk dinamika populasi dilakukan pada dua pertanaman jeruk per empat hari selama sembilan bulan (Maret 2011-November 2011) yakni pada minggu I dan III setiap bulannya. Hasil penelitian menunjukkan B. dorsalis complex lebih aktif pada pagi hari pukul 10.00-12.00 WIB. Kelimpahan puncak terjadi pada akhir Juni hingga awal Juli. Puncak populasi terjadi bersamaan dengan masa pematangan buah jeruk, rendahnya jumlah hari hujan dan curah hujan pada bulan Juni dan Juli. Terdapat hubungan yang signifikan antara jumlah hari hujan dan curah hujan dengan jumlah lalat buah yang tertangkap setiap bulan $\left(\mathrm{R}=0,79 ; \mathrm{Y}=289,34+14,23 \mathrm{X}_{1}\right.$ $\left.15,93 \mathrm{X}_{2} ; \mathrm{R}^{2}=0,62 ; \mathrm{P}<0.05\right)$. Dinamika populasi lalat buah pada dua lokasi pertanaman jeruk yang diselidiki menunjukkan pola yang relatif sama $\left(\mathrm{r}_{\mathrm{s}}=0.47 ; \mathrm{P}<0.05\right)$.
\end{abstract}

Kata kunci: lalat buah Bactrocera dorsalis complex, pola aktivitas harian, dinamika populasi

\section{PENDAHULUAN}

Kabupaten Karo yang berada di daerah pegunungan pada ketinggian $1400 \mathrm{~m}$ di atas permukaan laut merupakan salah satu pusat produksi buah-buahan, khususnya jeruk manis (Citrus sp.). Namun produksi jeruk dari Kabupaten tersebut sejak tahun 2003 telah mengalami penurunan yang sangat drastis. Hal itu terjadi karena buah tanaman jeruk yang berada di daerah ini diserang oleh lalat buah Bactrocera sp. (Diptera: Tephritidae). Menurut Hasyim et al. (2008) sebagai salah satu serangga hama penting tanaman hortikultura di daerah tropis dan subtropis, lalat buah meletakkan telurnya di bawah kulit buah, kemudian menetas menjadi larva dan selanjutnya mengkonsumsi daging buah. Buah yang terserang lalat buah akan menjadi lebih cepat busuk dan jatuh dari pohonnya sebelum waktunya (Hutasoit, 2004). 
Hama lalat buah diperkirakan telah merusak sekitar 17.000 hektar tanaman jeruk yang berada di daerah Kabupaten Karo dan menyebabkan produksi per hektarnya mengalami penurunan yang drastis menjadi 20 ton dari sebelumnya 60 ton. Bahkan kualitas buah jeruk yang dihasilkannya juga amat buruk sehingga harga jualnya di tingkat petani turun hingga 50\% (Manik \& Bangun, 2004).

Surat Kabar Harian Medan Bisnis pada 31 Mei 2004 memberitakan bahwa lalat buah yang menyerang tanaman jeruk yang berada di dataran tinggi provinsi Sumatra secara signifikan mampu mengurangi produksi sampai $70 \%$. Sehubungan dengan masalah tersebut pada bulan Mei 2004 gerakan pengendalian massal lalat buah telah dicanangkan, ditandai dengan pemukulan gong oleh Menteri Pertanian Republik Indonesia.

Salah satu langkah penting yang harus dilakukan dalam rangka monitoring dan pengendalian lalat buah yang menyerang tanaman jeruk adalah memahami bioekologi dari lalat buah tersebut. Sejumlah hasil penelitian tentang bioekologi lalat buah Bactrocera spp. telah dilaporkan oleh beberapa peneliti. Misalnya, Shehata et al. (2008) tentang biologi perkembangannya; Hasyim et al. (2008) tentang fluktuasi populasinya, Chen et al. (2006) perihal migrasi dan perubahan populasinya; dan Asokan et al. (2007) tentang biologi molekularnya.

Informasi mengenai bioekologi lalat buah Bactrocera spp. yang menyerang tanaman jeruk di Kabupaten Karo Sumatera Utara masih sangat terbatas. Penelitian yang telah dilakukan diantaranya masih berkaitan dengan keanekaragaman spesies dan pengaruh metil eugenol dalam pengendalian populasinya. Spesies lalat buah yang menyerang tanaman jeruk adalah Bactrocera dorsalis dan metil eugenol dengan menggunakan perangkap Steiner dapat dipergunakan untuk mengendalikan populasinya (Tobing et al., 2007).

Penelitian bertujuan untuk mengetahui pola aktivitas harian, kelimpahan dan dinamika populasi lalat buah dalam hubungannya dengan tingkat kematangan buah jeruk, perbedaan kelimpahan dan pola dinamika populasi lalat buah pada dua pertanaman jeruk serta hubungan antara faktor lingkungan (iklim) dengan kelimpahan/dinamika populasi lalat buah. Pemahaman tentang hal ini mempunyai kontribusi penting dalam monitoring ataupun pengendalian populasi lalat buah di lapangan. Kepentingan data semacam itu untuk monitoring dan pengendalian populasi serangga di lapangan saat menjadi hama pertanian telah dilaporkan oleh Manurung et al. (2004 \& 2005).

\section{METODE PENELITIAN}

Pola Aktivitas Harian. Penelitian dilakukan pada pertanaman jeruk manis di Desa Semangat Kecamatan Merdeka yang terletak pada ketinggian sekitar $1360 \mathrm{~m}$ di atas permukaan laut. Luas pertanaman jeruk tersebut $3000 \mathrm{~m}^{2}$ dan terdapat 500 pohon jeruk. Tanaman jeruk telah berumur sekitar 7 (tujuh) tahun. Pemerangkapan lalat buah dilakukan dengan menggunakan tipe perangkap Steiner yang telah dimodifikasi, yakni berupa botol bekas air mineral berukuran $1500 \mathrm{ml}$ yang salah satu bagian ujungnya diubah sedemikian rupa sehingga dapat berperan sebagai pintu masuk bagi lalat buah (Putra, 1997; Gupta \& Bhatia, 2000; Kardinan, 2003 \& Hasyim et al., 2008). Pada kawat yang terdapat pada bagian dalam botol digantungkan kapas sebesar ibu jari dan ditetesi zat pemikat metil eugenol sebanyak empat tetes. Perangkap digantung pada pohon jeruk pada ketinggian 1,5 meter dari permukaan tanah. Jumlah perangkap yang digunakan sebanyak 20 buah. Pemasangan perangkap berlangsung dari pukul 06.00 hingga pukul 18.00 WIB. Pemerangkapan dilakukan satu kali dalam seminggu dari bulan April hingga Mei 2011, sehingga secara total dilakukan delapan kali ulangan. Pengidentifikasian lalat buah di laboratorium dilakukan dengan bantuan mikroskop stereo binokuler merek Olympus SZ 51 dan mengacu kepada pustaka Drew \& Hancock (1994), White \& Elson-Harris (1994) dan Siwi et al. (2006). Variabel penelitian adalah jumlah lalat buah Bactrocera dorsalis complex yang tertangkap dalam perangkap per dua jam dan dinyatakan dalam proporsi (\%). Untuk mengetahui signifikansi perbedaan waktu aktivitas lalat buah pada pagi, siang dan sore hari digunakan uji Kruskal-Wallis (Zar, 2010).

Kelimpahan dan Dinamika Populasi. Penelitian dilakukan pada dua pertanaman jeruk, yakni di Desa Semangat Kecamatan Merdeka dan Desa Garingging Kecamatan Merek. Luas pertanaman jeruk di Desa Garingging juga sekitar $3000 \mathrm{~m}^{2}$ dan ditanami 500 pohon jeruk. Desa Garingging terletak sekitar $1352 \mathrm{~m}$ di atas permukaan laut. Jarak antar kedua pertanaman jeruk yang menjadi lokasi penelitian lebih kurang $25 \mathrm{~km}$. Pendekatan penelitiannya didasarkan kepada modifikasi metode yang dikemukakan oleh Gupta \& Bhatia (2000), Chen et al. (2006) dan Hasyim et al. (2008). Dalam hal ini, masing-masing pada kedua pertanaman jeruk dipasang 20 perangkap berupa botol air mineral bekas. Pada kapas yang tergantung dalam perangkap ditetesi 
empat tetes metil eugenol yang berperan sebagai zat pemikat bagi lalat buah. Selanjutnya perangkap ditempatkan pada ketinggian 1,5 m dari permukaan tanah. Setelah empat hari, lalat buah yang terperangkap diambil dan dibawa ke laboratorium untuk selanjutnya disortir, diidentifikasi dan dihitung jumlahnya. Pemerangkapan lalat buah dilakukan pada setiap minggu pertama dan minggu ketiga dari bulan Maret hingga November 2011, sehingga jumlah total sampling 17 kali. Selama masa pemerangkapan lalat buah, tingkat kematangan buah jeruk di lapangan juga diamati dan dicatat. Identifikasi dan penghitungan lalat buah dilakukan sebagaimana pada metode pola aktivitas harian di atas. Variabel penelitian adalah jumlah Bactrocera dorsalis complex yang terperangkap per empat hari selama 17 minggu penelitian. Dengan data tersebut dinamika populasi Bactrocera dorsalis complex selama 17 minggu pengamatan dapat diketahui, demikian juga dengan waktu terjadinya puncak populasinya. Signifikansi perbedaan kelimpahan lalat buah pada dua pertanaman jeruk diuji dengan menggunakan uji t, sedangkan perbedaan dinamika populasinya dengan analisis korelasi tata jenjang (Zar, 2010).

Data iklim berupa suhu, jumlah hari hujan dan curah hujan dari Badan Meteorologi dan Geofisika (BMG) setempat (stasiun Kuta Gadung) dipergunakan untuk mengetahui pengaruhnya terhadap kelimpahan dan dinamika populasi lalat buah. Dalam hal ini pengujiannya dilakukan dengan menggunakan uji regresi ganda bertahap (Zar, 2010).

\section{HASIL DAN PEMBAHASAN}

Pola Aktivitas Harian. Lalat buah Bactrocera dorsalis complex memiliki pola aktivitas harian yang lebih aktif pada pagi hari jam pukul 10.00-12.00 WIB hingga siang hari 12.00-14.00 WIB (Tabel 1). Hal ini ditunjukkan oleh banyaknya lalat buah yang tertangkap pada perangkap Steiner yang diberi metil eugenol. Pada pagi hari (10.00-12.00 WIB), proporsi lalat buah yang tertangkap sebesar 29\% (167 individu) dan siang hari 28\% (159 individu). Pada pagi hari (06.00-08.00 WIB) dan sore hari (16.00-18.00 WIB) proporsi lalat buah yang aktif relatif sedikit, yakni hanya 2\% (12 individu) dan 6\% (35 individu). Berdasarkan data jumlah lalat buah yang tertangkap dapat dikemukakan puncak waktu aktif lalat buah pada pertanaman jeruk terjadi pada pagi hari pukul 10.00-12.00 WIB. Hasil uji Kruskal-Wallis menunjukkan perbedaan waktu aktif lalat buah tersebut sangat signifikan $(\mathrm{H}=26,82 ; \mathrm{P}<0,01)$.

Lebih banyaknya lalat buah yang aktif pada pagi hari hingga siang hari (10.00-14.00 WIB) dan sebaliknya relatif sedikitnya lalat buah yang aktif pada pagi hari pukul 06.00-08.00 WIB dan sore hari pukul 16.00-18.00 WIB mungkin erat kaitannya dengan sifat lalat buah yang ektoterm dan suhu lingkungan yang ada di dataran tinggi tanah Karo. Dalam hal ini agar lalat buah tersebut dapat memulai aktivitasnya (seperti menggerakkan mata, sungut, kaki, sayap hingga akhirnya terbang mencari makanan dan pasangan hidup) harus terlebih dahulu suhu ambang tubuhnya (threshold temperature) terlampaui (David \& Ananthakrishnan, 2006; Honek \& Kocourek, 1990). Menurut Liu \& Yeh (1982) dan Chen et al. (2006) suhu ambang tubuh lalat buah sekitar $18^{\circ} \mathrm{C}$. Sementara itu, menurut Badan Meteorologi dan Geofisika (BMG) setempat suhu rata-rata pada pagi hari di dataran tinggi Kabupaten Karo pada bulan April dan Mei (waktu penelitian dilaksanakan) adalah $16,9-17,3^{\circ} \mathrm{C}$, siang hari $22,9-23,5^{\circ} \mathrm{C}$ dan sore hari $19,1-19,4^{\circ} \mathrm{C}$. Jadi kondisi suhu lingkungan yang masih rendah pada pagi hari pukul 06.0008.00 WIB mungkin yang menyebabkan lebih sedikitnya proporsi lalat buah yang tertangkap pada pagi, demikian juga pada sore hari pukul 16.00-18.00 WIB jika dibandingkan dengan pada pagi hari pukul 10.00-12.00 WIB hingga siang hari pukul 12.00-14.00 WIB.

Hasil yang diperoleh pada penelitian ini menkonfirmasi hasil penelitian yang telah dilaporkan oleh Tobing et al. (2007) yang menyatakan bahwa lalat buah

Tabel 1. Proporsi lalat buah Bactrocera dorsalis complex yang tertangkap pada perangkap Steiner dari pukul 06.00-18.00 WIB pada pertanaman jeruk di Kabupaten Karo Provinsi Sumatera Utara

\begin{tabular}{cccc}
\hline No & Waktu & Jumlah tangkapan (individu) & Proporsi (\%) \\
\hline 1 & $06.00-08.00$ & 12 & 2 \\
2 & $08.00-10.00$ & 131 & 23 \\
3 & $10.00-12.00$ & 167 & 29 \\
4 & $12.00-14.00$ & 159 & 28 \\
5 & $14.00-16.00$ & 67 & 12 \\
6 & $16.00-18.00$ & 35 & 6 \\
\hline
\end{tabular}


lebih aktif pada pagi hari, akan tetapi penelitian tersebut belum mengungkapkan waktu aktifnya pada pagi hari tersebut. Sementara hasil penelitian ini menunjukkan bahwa waktu aktif lalat buah tersebut yaitu pada pukul 10.00-12.00 WIB. Selanjutnya, jika dibandingkan dengan hasil yang telah dilaporkan oleh Chen et al. (2006) relatif berbeda. Dalam hal ini Chen et al (2006) menyatakan populasi lalat buah Bactorcera dorsalis pada kebun Jambu mencapai puncaknya pada sore hari. Perbedaan hasil itu dapat dijelaskan karena Chen et al. (2006) melakukan pemerangkapan hanya pada pagi hari pukul 09.00 dan sore hari pukul 15.00 WIB. Itu berarti data lalat buah yang tertangkap pada siang hari tidak tersedia.Hal itulah mungkin yang menyebabkan mengapa hasil yang diperoleh pada penelitian ini berbeda dengan hasil yang telah dilaporkan oleh Chen et al. (2006) tersebut.

Kelimpahan dan Dinamika Populasi. Selama penelitian diperoleh lalat buah Bactrocera dorsalis complex sebanyak 2519 individu pada pertanaman jeruk di Desa Garingging dan 2160 individu di Desa Semangat
(Tabel 2). Jadi kelimpahan lalat buah pada pertanaman jeruk yang terdapat di Desa Garingging lebih banyak dibandingkan dengan yang terdapat di desa Semangat. Perbedaan kelimpahan lalat buah tersebut berdasarkan hasil uji t tidak signifikan ( $\mathrm{t}$ hitung $=1,10 ; \mathrm{P}>0,05$ ). Kelimpahan tertinggi lalat buah pada desa Garingging 340 individu terjadi pada Minggu III bulan Juni sedangkan yang terendahnya 40 individu terjadi pada Minggu I bulan Mei. Sementara itu, di Desa Semangat, kelimpahan tertingginya hanya mencapai 240 individu terjadi pada Minggu I bulan Juli dan terendahnya 30 individu terjadi juga pada Minggu I bulan Mei. Oleh karena itu, puncak kelimpahan lalat buah pada kedua pertanaman jeruk tersebut terjadi pada akhir bulan Juni hingga awal bulan Juli. Lebih lanjut dapat dikemukakan populasi lalat buah berfluktuasi seiring dengan berjalannya waktu. Dalam hal ini pada periode bulan Maret - April 2011 jumlahnya relatif lebih banyak dibandingkan pada bulan Mei yang jumlahnya menurun. Pada bulan Juni dan Juli bahkan hingga bulan Agustus jumlahnya meningkat lagi. Selanjutnya pada bulan September jumlahnya menurun lagi dan kemudian

Tabel 2. Kelimpahan lalat buah Bactrocera dorsalis Compleks per 20 perangkap dari Maret hingga November 2011 di dua pertanaman jeruk di Kabupaten Karo-Propinsi Sumatera Utara

\begin{tabular}{cllc}
\hline No & Waktu & $\begin{array}{c}\text { Kelimpahan lalat buah (ekor) } \\
\text { di Desa Garingging }\end{array}$ & $\begin{array}{c}\text { Kelimpahan lalat buah (ekor) } \\
\text { di Desa Semangat }\end{array}$ \\
\hline 1 & I. Maret & 170 & 105 \\
2 & III. Maret & 105 & 138 \\
3 & I. April & 182 & 192 \\
4 & III. April & 60 & 96 \\
5 & I. Mei & 40 & 30 \\
6 & III. Mei & 136 & 84 \\
7 & I. Juni & 304 & 146 \\
8 & III. Juni & 340 & 188 \\
9 & I. Juli & 336 & 240 \\
10 & III. Juli & 228 & 232 \\
11 & I. Agustus & 80 & 210 \\
12 & III. Agustus & 100 & 188 \\
13 & I. September & 60 & 99 \\
14 & III. September & 96 & 25 \\
15 & I. Oktober & 105 & 10 \\
16 & III. Oktober & 177 & 96 \\
17 & I. November & 188 & 81 \\
\hline Jumlah total & 2519 & 2160 \\
Rataan & Simpangan baku & 59,23 & 72,05 \\
Simp & 95,36 & \\
\hline
\end{tabular}


meningkat lagi hingga minggu I bulan November 2011. Adanya perubahan kelimpahan populasi ataupun dinamika populasi lalat buah Bactrocera spp. pada berbagai tanaman inang telah dilaporkan oleh sejumlah peneliti, diantaranya Gupta \& Bahatia (2000); Chen et al. (2006) dan Hasyim et al. (2008). Perubahan kelimpahan tersebut erat kaitannya dengan keadaan faktor lingkungan abiotik dan abiotik dimana lalat buah tersebut hidup ataupun berada (Chen et al., 2006 dan Hasyim et al., 2008).

Berdasarkan pengamatan di lapangan, tampaknya ada hubungan antara jumlah lalat buah yang tertangkap dengan fase pertumbuhan dan perkembangan tanaman jeruk atau dengan kata lain tingkat kematangan buah jeruk. Kelimpahan tertinggi diperoleh bersamaan dengan ukuran buah jeruk sebesar bola kasti dan warnanya hijau kekuningan, sedangkan kelimpahan terendah terjadi saat buah jeruk berukuran kecil sebesar kelereng dan masih berwarna kehijaun.

Ketika sampling pertama dilakukan pada Minggu I bulan Maret 2011, buah jeruk baru saja dipanen, tepatnya pada bulan Februari. Pada saat itu yang tersisa hanyalah buah jeruk yang berukuran kecil (sebesar kelereng) dan berwarna hijau. Kondisi jeruk yang sedemikian mungkin yang menjadi penyebab mengapa jumlah lalat buah yang tertangkap pada bulan Mei relatif sedikit.

Selanjutnya, pada bulan Juni dan Juli, buah jeruk di lapangan telah ada dalam ukuran yang relatif besar (sebesar bola kasti) dan lebih matang yang ditandai dengan perubahan warna dari hijau menjadi kuning. Pada kondisi jeruk yang sedemikian jumlah lalat buah yang tertangkap relatif banyak. Terjadinya hal itu mungkin erat kaitannya dengan bau ataupun aroma ester yang dihasilkan buah jeruk saat mengalami perubahan warna dari hijau ke kuning, demikian juga dengan warna kuning dari buah jeruk. Hal ini sesuai dengan apa yang dikemukakan oleh Palti \& Ausher (1983), Kalie (1992) dan juga Kusnaedi (1995), bahwa bau atau aroma ester dan visualisasi kuning dari buah jeruk sangat disukai oleh lalat buah. Kedua faktor tersebut mungkin yang menyebabkan jumlah lalat buah yang tertangkap pada bulan Juni hingga Juli 2011 pada pertanaman jeruk menjadi meningkat. Adanya hubungan antara tingkat kematangan buah dengan dinamika/fluktuasi populasi lalat buah di lapangan lebih lanjut juga telah dilaporkan oleh Gupta \& Bahatia (2000), Chen et al. (2006) dan Hasyim et al. (2008).

Pada awal Agustus 2011, buah jeruk telah dipanen pada Desa Garingging sedangkan di Desa Merdeka pada akhir Agustus 2011. Keadaan seperti itu menyebabkan buah jeruk yang tersisa di lapangan hanya buah yang berukuran kecil dengan warna hijau. Kondisi tersebut menyebabkan visualisasi kuning sebagai warna penarik bagi lalat buah, demikian juga halnya dengan tidak adanya aroma ester yang keluar dari buah jeruk menyebabkan jumlah lalat buah yang tertangkap mulai pertengahan bulan Agustus 2011 di Desa Garingging dan bulan September 2011 di Desa Semangat menjadi berkurang.

Selanjutnya, dengan berubahnya ukuran jeruk, dalam hal ini menjadi lebih besar dan mulai adanya jeruk yang berwarna hijau kekuningan pada bulan Oktober 2011, jumlah populasi lalat buah kembali meningkat. Peningkatan itu tampak terjadi mulai bulan Oktober hingga awal bulan November 2011.

Sementara itu, berdasarkan hasil uji korelasi tata jenjang dapat dikemukakan lebih lanjut bahwa kecenderungan pola fluktuasi yakni naik turunnya populasi lalat buah pada kedua pertanaman jeruk yang diselidiki (antara Desa Garingging dan Semangat) relatif sama. Hal itu ditunjukkan oleh adanya korelasi yang signifikan antara jumlah lalat buah yang tertangkap per satuan waktu pada Desa Garingging dengan jumlah yang tertangkap di Desa Semangat $\left(r_{s}=0,47 ; P<0,05\right)$ (Gambar 1). Terjadinya kesamaan pola dinamika populasi tersebut mungkin erat kaitannya dengan kesamaan waktu berbunga, pertumbuhan dan perkembangan buah jeruk, terutama masa perubahan warna buah dari hijau ke kuning bahkan waktu panen jeruk pada kedua areal pertanaman yang diselidiki relatif sama, termasuk kondisi faktor abiotik lingkungannya terutama suhu, jumlah hari hujan dan curah hujannya.

Di samping faktor tingkat kematangan buah, faktor lain yang juga turut berperan dalam mempengaruhi kelimpahan dan dinamika populasi lalat buah pada kedua lokasi penelitian adalah faktor jumlah curah hujan $\left(X_{1}\right)$ dan hari hujan $\left(X_{2}\right)$ (Tabel 3). Dalam hal ini hasil analisis regresi ganda bertahap menunjukkan hanya faktor jumlah curah hujan dan hari hujan yang secara bersama-sama berpengaruh atau berkorelasi signifikan dengan kelimpahan dan dinamika populasi lalat buah $\left(\mathrm{R}=0,79 ; \mathrm{Y}=289,34+14,23 \mathrm{X}_{1}-15,93 \mathrm{X}_{2} ; \mathrm{R}^{2}=0,62\right.$; $\mathrm{P}<0,05)$, sedangkan suhu lingkungan setempat tidak berpengaruh $\left(r=0,05 ; Y=-3,63 X_{3}+216,6 ; R^{2}=0,002\right.$; $\mathrm{P}>0,05)$. Sehubungan dengan itu, jumlah curah hujan dan hari hujan yang relatif rendah pada bulan Juni dan Juli juga perlu mendapat perhatian khusus dari petani jeruk dalam rangka pengendalian populasi lalat buah di lapangan. Adanya pengaruh faktor abiotik lingkungan seperti jumlah curah hujan dan hari hujan dalam mempengaruhi kelimpahan dan dinamika populasi lalat 


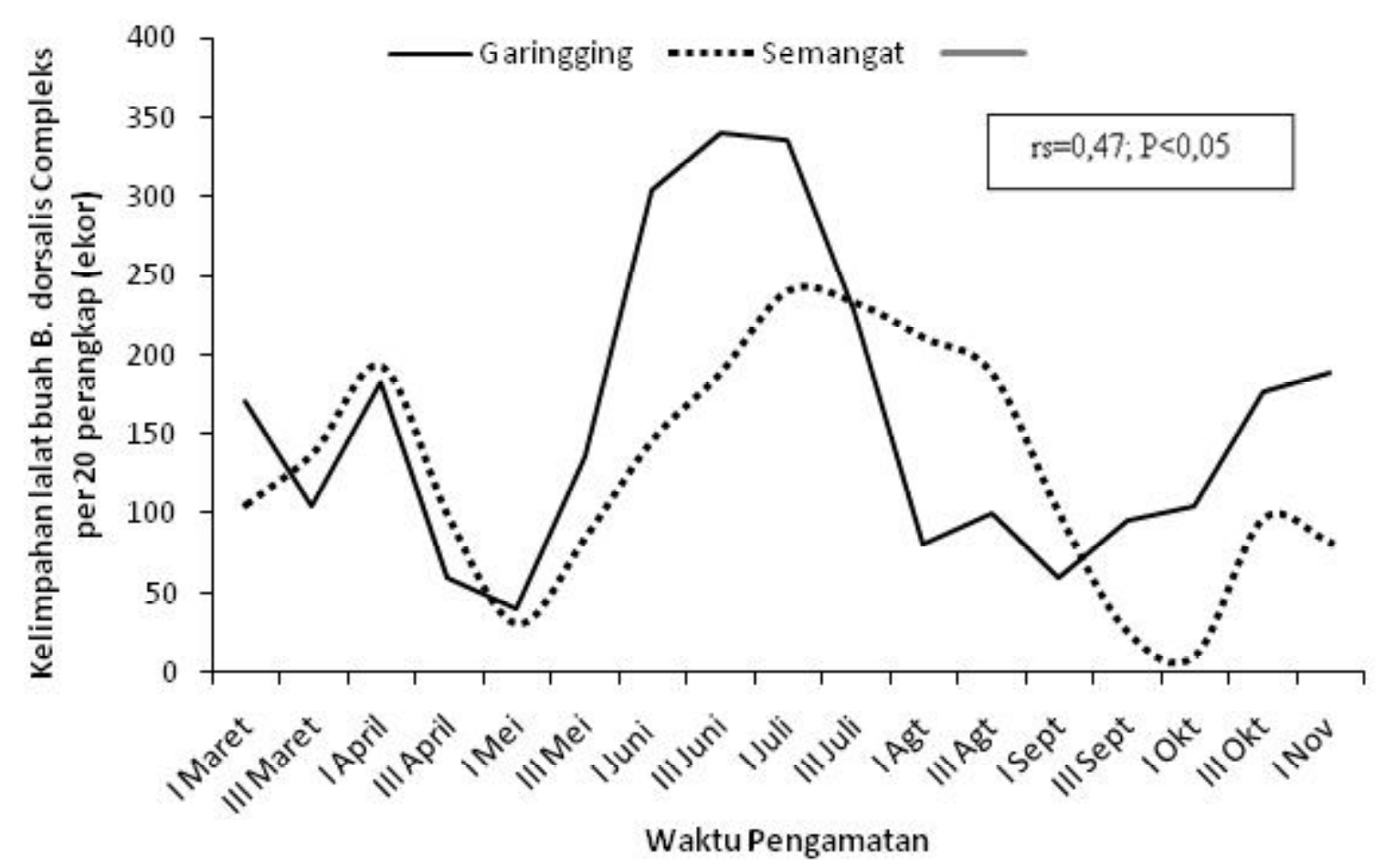

Gambar 1. Pola dinamika populasi lalat buah Bactrocera dorsalis complex pada pertanaman jeruk di dua Desa di Kabupaten Karo dari bulan Maret hingga November 2011.

Tabel 3. Faktor iklim (curah hujan, hari hujan dan suhu) serta kelimpahan rata-rata per bulan lalat buah Bactrocera dorsalis complex yang tertangkap dari bulan Maret hingga November 2011 di Kabupaten Karo Provinsi Sumatera Utara

\begin{tabular}{lcccc}
\hline Waktu & Curah Hujan $(\mathrm{ml})$ & Hari Hujan $(\mathrm{d})$ & Suhu $\left({ }^{\circ} \mathrm{C}\right)$ & Jumlah Lalat Buah (Ekor) \\
\hline Maret & 4,7 & 17 & 19 & 129 \\
April & 6,8 & 15 & 19,1 & 133 \\
Mei & 2,6 & 13 & 19,5 & 73 \\
Juni & 2,1 & 9 & 19,1 & 245 \\
Juli & 0,4 & 2 & 18,9 & 259 \\
Agustus & 11,1 & 19 & 18,6 & 145 \\
September & 3,8 & 13 & 18,7 & 70 \\
Oktober & 5,8 & 18 & 18,7 & 96 \\
November & 7,6 & 17 & 21,6 & 134 \\
\hline
\end{tabular}

buah Bactrocera spp. telah juga dilaporkan oleh Chen et al. (2006) dan Hasyim et al. (2008).

\section{SIMPULAN}

Lalat buah Bactrocera dorsalis complex pada pertanaman jeruk di dataran tinggi Kabupaten KaroProvinsi Sumatera Utara lebih aktif pada pagi hari pukul 10.00-12.00 WIB. Puncak kelimpahan populasinya terjadi pada bulan Juni hingga Juli bersamaan dengan terjadinya masa pematangan buah jeruk dan relatif sedikitnya jumlah hari hujan dan curah hujan. Dinamika populasi lalat buah Bactrocera dorsalis complex pada dua lokasi pertanaman jeruk yang diselidiki menunjukkan pola yang relatif sama. Jumlah hari hujan dan curah hujan setempat secara bersama-sama berkorelasi negatif terhadap kelimpahan dan dinamika populasi lalat buah. 


\section{SANWACANA}

Tim Peneliti mengucapkan terimakasih kepada Ditjen Dikti-DP2M Dikti Depdiknas yang telah mendanai pelaksanaan penelitian ini dengan Surat Perjanjian Hibah Penugasan Penelitian Fundamental No.199/SP2H/PL/ Dit.Litabmas/IV/2011 tanggal 14 April 2011. Demikian juga kepada Parningotan Sijabat pada BMG-Stasiun Klimatologi Kuta Gadung Kabupaten Karo yang telah bersedia menyediakan data suhu, jumlah hari hujan dan curah hujan.

\section{DAFTAR PUSTAKA}

Asokan R, Kumar NKK \& Verghese A. 2007. Molecular identification of fruit flies Bactrocera spp. (Diptera: Tephritidae) using mitochondrial cytochrome oxidase I. Current Science 93 (12): 1668-1669.

Drew RAI \& Hancock DL. 1994. The Bactrocera dorsalis complex of fruit flies (Diptera: Tephritidae: Dacinae) in Asia. Bulletin of Entomological Research Suppl. (2): 1-68.

Chen CC, Dong YJ, Lie CT, Lin KY \& Cheng LL. 2006. Movement of the oriental fruit fly, Bactrocera dorsalis (Hendel) (Diptera: Tephritidae) in a Guava orchard with special reference to its population changes. Formosan Entomol. 26: 143159.

David BV \& Ananthakrishnan TN. 2006. General and Applied Entomology. Tata McGraw-Hill Publishing Company Limited, New Delhi.

Gupta D \& Bahatia R. 2000. Population fluctuations of fruit flies, Bactrocera spp. in sub mountainous mango and guava orchards. J. Appl. Hort. 2(1): 47-49.

Hasyim A, Muryati \& de Kogel WJ. 2008. Population fluctuation of adult males of the fruit fly Bactrocera tau Walker (Diptera: Tephritidae) in passion fruit orchards in relation to abiotic factors and sanitation. Indonesian Journal of Agricultural Sciences 9(1): 29-33.

Honek A \& Kocourek F. 1990. Temperature and development time in insects: A general relationship between thermal constants. Zool. Jb. Syst. 117: 401-439.
Hutasoit K. 2004. Petani dan Kebun Jeruk. http:// www.mediaindo.12.co.id./berita.asp (Diakses 4 Maret 2010).

Kalie MB. 1992. Mengatasi Buah Rontok, Busuk dan Berulat. Penerbar Swadaya, Jakarta.

Kardinan A. 2003. Tanaman Pengendali Lalat Buah. Agromedia Pustaka, Jakarta.

Kusnaedi.1995. Pengendalian Hama Tanpa Pestisida. Penebar Swadaya, Jakarta.

Liu YC \& Yeh CC. 1982. Population fluctuation of oriental fruit fly Dacus dorsalis Hendel in sterile fly release and control area. Chinese J. Entomol. 2: 57-70.

Manik L \& Bangun A. 2004. Sumut Terima Alokasi Terbesar, Deptan Siapkan Rp.1 Miliar.Kendalikan Hama Lalat Buah. http/www.sebayak.org./ berita.php.id (Diakses 4 Maret 2010).

Manurung B, Witsack W, Mehner S, Grüntzig M \& Fuchs E. 2004. The epidemiology of Wheat dwarf virus in relation to occurrence of the leafhopper Psammotettix alienus in Middle-Germany. Virus Research 100: 109-113.

Manurung B, Witsack W, Mehner S, Grüntzig M \& Fuchs E. 2005. Studies on biology and population dynamics of the leafhopper Psammotettix alienus Dahlb. (Homoptera:Auchenorrhyncha) as vector of wheat dwarf virus (WDV) in Saxony-Anhalt, Germany. Journal of Plant Diseases and Protection 112 (5): 497-50

Palti J \& Ausher R. 1983. Advisory Work in Crop Pest and Disease Management. Springer-Verlag, New York.

Putra NS. 1997. Hama Lalat Buah dan Pengendalianya. Penerbit Kanisius, Yogjakarta.

Shehata NF, Younes MWF \& Mahmoud YA. 2008. Biological studies on the peach fruit fly Bactrocera zonata (Saunders) in Egypt. Journal of Applied Sciences Research 4(9): 1103-1106.

Siwi SS, Hidayat P \& Suputa. 2006. Taksonomi dan Bioekologi Lalat Buah Penting di Indonesia (Diptera: Tephritidae). BB Biogen \& Dept. Agriculture, Fisheries \& Forestry Australia, Bogor. 
Tobing MC, Marheni, Mariati \& Sipayung R. 2007. Pengaruh metil eugenol dalam pengendalian lalat buah (Bactrocera dorsalis) pada pertanaman jeruk. Jurnal Natur Indonesia 9 (2): 127-130.
White IM \& Elson-Harris MM. 1994. Fruit Flies of Economic Significance, Their Identification and Bionomics. CAB International, WallingfordUK.

Zar JH. 2010. Biostatistical Analysis. $5^{\text {th }}$ Edition. Prentice-Hall International, Inc., New Jersey. 